United Nations Development Programme

Country Office for Afghanistan

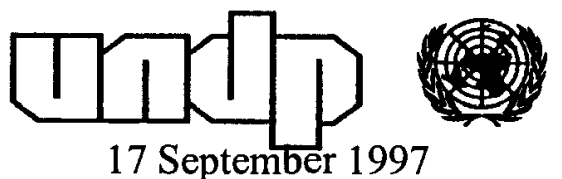

17 September 1997

To: $\quad$ Members of the Gender Advisory Group

From: Gulalai Habib $($ H

Gender Focal Point

Subject: $\quad$ Universal Declaration of Human Rights (UDHR) \& Convention on the Elimination of all forms of Discrimination Against Women (CEDAW)

Attached please find a copy of the above documents in English. We are planning to prepare the Pashto and Dari translation, in the near future.

We hope that these documents will be useful for your daily work and for rehearsal in the following events during the current year:

1. A gender mission under the direction of UN Coordinator and leadership of the Special Advisor to the Secretary General on Gender Issues and Director of The Division of the Advancement of Women, will start at the beginning of October and expected to be completed within six weeks. The main objectives of the mission are to translate the policy statements of the Secretary General into clear and practical operational guidelines for all UN Agencies working for Afghanistan, to establish a set of monitoring indicators (qualitative and quantitative) and unified and coherent actions that will guide the implementation of UN programmes at the field level.

2. The Gender Advisory Group (GAG) of UN \& NGOs for Afghanistan and the Gender Resource Center, are planning to organize an important workshop on the development of the GAG and RC for serving the aid community, more efficiently and effectively.

3. The world will celebrate 10 December 1998, the 50th anniversary of the adoption by the United Nations of the Universal Declaration of the Human Rights. During 25 November - 10 December 1997 and 1998, will be 16 days of activism for the 1998: Global Campaign for Women's Human Rights. The beginning of the Campaign, i.e. 25 November 1997 is allocated for a day of solidarity with Afghan women.

4. The Gender and Development Programme of the Asian and Pacific Development Centre intends to have regional consultation on the issue of refugee women, and women in situation of armed confliot. The Consultation will hopefully take place during October 1997 in Asia, with the following objective: a) to provide a forum for refugee women/women in situations of armed conflict to share their experiences; $b$ ) to prepare a regional situation analysis of the conditions and gender impacts of state/territorial disputes and armed conflicts on women and children; b) to identify national, regional and international strategies to address the problems.

All the best.

cc: $\quad$ Programme Manager of the P.E.A.C.E Initiative (+encl.)

UNDP/UNOCHA' POs (+encl.)

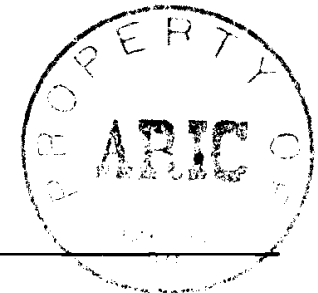

Temporary Address:

House 292, Street 55, F-10/4, Islamabad, Pakistan: Tel: 9251 211451, Fax: 9251211450 


\section{UNIVERSAL DECLARATION OF HUMAN RIGHTS}

On December 10, 1948 the General Assembly of the United Nations adopted and proclaimed the Universal Declaration of Human Rights the full text of which appears in the following pages. Following this historic act the Assembly called upon ail Member countries to publicize the text of the Declaration and "to cause it to be disseminated, displayed, read and

expounded principally in schools and other educational institutions, without distinction based on the political status of countries or territories."

\section{PREAMBLE}

Whereas recognition of the inherent dignity and of the equal and inalienable rights of all members of the human family is the foundation of freedom, justice and peace in the world,

Whereas disregard and contempt for human rights have resulted in barbarous acts which have outraged the conscience of mankind, and the advent of a world in which human beings shall enjoy freedom of speech and belief and freedom from fear and want has been proclaimed as the highest aspiration of the commonpeople,

Whereas it is essential, if man is not to be compelled to have recourse, as a last resort, to rebellion against tyranny and oppression, that human rights should be protected by the rule of law,

Whereas it is essential to promote the development of friendly relations between nations,

Whereas the peoples of the United Nations have in the Charter reaffirmed theirfaith in fundamental human rights, in the dignity and worth of the human person and in the equal rights of men and women and have determined to promotesocial progress and better standards of life in larger freedom, $\square$ Whereas Member States have pledged themselves to achieve, in co-operation withthe United Nations, the promotion of universal respect for and observance of human rights and fundamental freedoms,

Whereas a common understanding of these rights and freedoms is of the greatestimportance for the full realization of this pledge,

Now, Therefore,

\section{THE GENERAL ASSEMBLY}

\section{proclaims}

THIS UNIVERSAL DECLARATION OF HUMAN RIGHTS as a common standard of achievementfor all peoples and all nations, to the end that every individual and every organ of society, keeping this Declaration constantly in mind, shall strive byteaching and education to promote respect for these rights and freedoms and byprogressive measures, national and international, to secure their universal and effective recognition and observance, both among the peoples of Member States themselves and among the peoples of territories under their jurisdiction.

\section{Article 1.}

All human beings are born free and equal in dignity and rights. They are endowed with reason and conscience and should act towards one another in a spirit of brotherhood. 
conscience and should act towards one another in a spirit of brotherhood.

\section{Article 2.}

Everyone is entitled to all the rights and freedoms set forth in this Declaration, without distinction of any kind, such as race, colour, sex, language, religion, political or other opinion, national or social origin, property, birth or other status. Furthermore, no distinction shall be made on the basis of the political, jurisdictional or international status of the country or territory to which a person belongs, whether it be independent, trust, non-self-governing or under any other limitation of sovereignty.

\section{Article 3.}

Everyone has the right to life, liberty and security of person.

\section{Article 4.}

No one shall be held in slavery or servitude; slavery and the slave trade shall be prohibited in all their forms

\section{Article 5.}

No one shall be subjected to torture or to cruel, inhuman or degrading treatment or punishment.

\section{Article 6.}

Everyone has the right to recognition everywhere as a person before the law.

\section{Article 7.}

All are equal before the law and are entitled without any discrimination to equal protection of the law. All are entitled to equal protection against any discrimination in violation of this Declaration and against any incitement to such discrimination.

\section{Article 8.}

Everyone has the right to an effective remedy by the competent national tribunals for acts violating the fundamental rights granted him by the constitution or by law.

\section{Article 9.}

No one shall be subjected to arbitrary arrest, detention or exile.

\section{Article 10.}

Everyone is entitled in full equality to a fair and public hearing by an independent and impartial tribunal, in the determination of his rights and obligations and of any criminal charge against him.

\section{Article 11.}


( I) Everyone charged with a penal offence has the right to be presumed innocent until proved guilty according to law in a public trial at which he has had all the guarantees necessary for his defence.

(2) No one shall be held guilty of any penal offence on account of any act or omission which did not constitute a penal offence, under national or international law, at the time when it was committed Nor shall a heavier penalty be imposed than the one that was applicable at the time the penal offence was coinmitted.

\section{Article 12.}

No one shall be subjected to arbitrary interference with his privacy, family, home or correspondence, nor to attacks upon his honour and reputation Everyone has the right to the protection of the law against such interference or attacks.

\section{Article 13.}

(1) Everyone has the right to freedom of movement and residence within the borders of each state.

(2) Everyone has the right to leave any country, including his own, and to return to his country.

\section{Article 14.}

(1) Everyone has the right to seek and to enjoy in other countries asylum from persecution.

(2) This right may not be invoked in the case of prosecutions genuinely arising from non-political crimes or from acts contrary to the purposes and principles of the United Nations.

\section{Article 15.}

(1) Everyone has the right to a nationality.

(2) No one shall be arbitrarily deprived of his nationality nor denied the right to change his nationality.

\section{Article 16.}

(1) Men and women of full age, without any limitation due to race, nationality or religion, have the right to marry and to found a family. They are entitled to equal rights as to marriage, during marriage and at its dissolution.

(2) Marriage shall be entered into only with the free and full consent of the intending spouses.

(3) The family is the natural and fundamental group unit of society and is entitled to protection by society and the State.

\section{Article 17.}

(1) Everyone has the right to own property alone as well as in association with others.

(2) No one shall be arbitrarily deprived of his property. 
(2) No one shall be arbitrarily deprived of his property.

\section{Article 18.}

Everyone has the right to freedom of thought, conscience and religion; this right includes freedom to change his religion or belief, and freedom, either alone or in community with others and in public or private, to manifest his religion or belief in teaching, practice, worship and observance.

\section{Article 19.}

Everyone has the right to freedom of opinion and expression; this right includes freedom to hold opinions without interference and to seek, receive and impart information and ideas through any media and regardless of frontiers.

\section{Article 20.}

(1) Everyone has the right to freedom of peaceful assembly and association.

(2) No one may be compelled to belong to an association.

\section{Article 21.}

(1) Everyone has the right to take part in the government of his country, directly or through freely chosen representatives.

(2) Everyone has the right of equal access to public service in his country.

(3) The will of the people shall be the basis of the authority of government; this will shall be expressed in periodic and genuine elections which shall be by universal and equal suffrage and shall be held by secret vote or by equivalent free voting procedures.

\section{Article 22.}

Everyone, as a member of society, has the right to social security and is entitled to realization, through national effort and international co-operation and in accordance with the organization and resources of each State, of the economic, social and cultural rights indispensable for his dignity and the free development of his personality.

\section{Article 23.}

(1) Everyone has the right to work, to free choice of employment, to just and favourable conditions of work and to protection against unemployment.

(2) Everyone, without any discrimination, has the right to equal pay for equal work.

(3) Everyone who works has the right to just and favourable remuneration ensuring for himself and his family an existence worthy of human dignity, and supplemented, if necessary, by other means of social protection.

(4) Everyone has the right to form and to join trade unions for the protection of his interests. 
(4) Everyone has the right to form and to join trade unions for the protection of his interests.

\section{Article 24.}

Everyone has the right to rest and leisure, including reasonable limitation of working hours and periodic holidays with pay.

\section{Article 25.}

(1) Everyone has the right to a standard of living adequate for the health and well-being of himself and of his family, including food, clothing, housing and medical care and necessary social services, and the right to security in the event of unemployment, sickness, disability, widowhood, old age or other lack of livelihood in circumstances beyond his control.

(2) Motherhood and childhood are entitled to special care and assistance. All children, whether born in or out of wedlock, shall enjoy the same social protection.

\section{Article 26.}

(1) Everyone has the right to education. Education shall be free, at least in the elementary and fundamental stages Elementary education shall be compulsory Technical and professional education shall be made generally available and higher education shall be equally accessible to all on the basis of merit.

(2) Education shall be directed to the full development of the human personality and to the strengthening of respect for human rights and fundamental freedoms. It shall promote understanding, tolerance and friendship among all nations, racial or religious groups, and shall further the activities of the United Nations for the maintenance of peace.

(3) Parents have a prior right to choose the kind of education that shall be given to their children.

\section{Article 27.}

(1) Everyone has the right freely to participate in the cultural life of the community, to enjoy the arts and to share in scientific advancement and its benefits.

(2) Everyone has the right to the protection of the moral and material interests resulting from any scientific, literary or artistic production of which he is the author.

\section{Article 28.}

Everyone is entitled to a social and international order in which the rights and freedoms set forth in this Declaration can be fully realized.

\section{Article 29.}

(1) Everyone has duties to the community in which alone the free and full development of his personality is possible.

(2) In the exercise of his rights and freedoms, everyone shall be subject only to such limitations as are determined by law solely for the purpose of securing due recognition and respect for the rights and 
freedoms of others and of meeting the just requirements of morality, public order and the general welfare in a democratic society.

(3) These rights and freedoms may in no case be exercised contrary to the purposes and principles of the United Nations.

\section{Article 30.}

Nothing in this Declaration may be interpreted as implying for any State, group or person any right to engage in any activity or to perform any act aimed at the destruction of any of the rights and freedoms set forth herein. 


\title{
DECLARATION ON THE ELIMINATION OF VIOLENCE AGAINST WOMEN
}

\author{
(Adopted by the United Nations General Assembly on 20 December 1993, GA Res \\ 48/104)
}

The General Assembly,

Recognising the urgent need for the universal application to women of the rights and principles with regard to equality, security, liberty, integrity and dignity of all human persons,

Noting that those rights and principles are enshrined in international instruments, including the Universal Declaration of Human Rights, ${ }^{1}$ the International Covenant on Civil and Political Rights, ${ }^{2}$ the International Covenant on Economic, Social and Cultural Rights, ${ }^{3}$ the Convention on the Elimination of All Forms of Discrimination against Women, ${ }^{4}$ and the Convention against Torture and Other Cruel, Inhuman or Degrading Trearment or Punishment, ${ }^{5}$

Recognising that the effective implementation of the Convention on the Elimination of All Forms of Discrimination against Women would contribute to the elimination of violence against women and that the Declaration on the Elimination of Violence against Women, annexed to the present resolution, will strengthen and complement that process,

Concemed that violence against women is an obstacle to the achievement of equality, development and peace, as recognised in the Nairobi Forward-looking Strategies for the Advancement of Women, ${ }^{6}$ which recommend a set of measures to combat violence against women, and to the full implementation of the Convention on the Elimination of All Forms of Discrimination against Women,

Affirming that violence against women both violates and impairs or nullifies the enjoyment by women of human rights and fundamental freedoms, and concerned about the long-standing failure to protect and promote those rights and freedoms in relation to violence against women,

Recognising that violence against women is a manifestation of historically unequal power relations between men and women, which have led to domination over and discrimination against women by men and to the prevention of their full advancement, and that violence against women is one of the crucial social mechanisms by which women are forced into a subordinate position compared with men,

Concerned that some groups of women, such as women belonging to minority groups, indigenous women, refugee women, migrant women, women living in rural or remote communities, destitute women, women in institutions or in detention, female children, women with disabilities, elderly women and women in situations of armed conflict, are especially vulnerable to violence,

Recalling Economic and Social Council resolution 1990/15 of 24 May 1990, in the annex to which it was

\footnotetext{
${ }^{1}$ Resolution 217 A (III).

2 Resolution 2200 A (XXI), annex.

${ }^{3}$ Resolution 2200 A (XXI), annex.

${ }^{4}$ Resolution 34/180, annex.

${ }^{5}$ Resolution 39/46, annex.

${ }^{6}$ Report of the World Conference to Review and Appraise the Achievements of the United Nations Decade for Women: Equality. Development and Peace, Nairobi. 15-26 July 1985 (United Nations publication, Sales No. E.85.IV.10), chap. I, sect. A.
} 
recognised that violence against women in the family and society was pervasive and cut across lines of income, class and culture, and had to be matched by urgent and effective steps to eliminate its incidence,

Recalling also Economic and Social Council resolution 1991/18 of 30 May 1991, in which the Council recommended the development of a framework for an international instrument that would address explicitly the issue of violence against women,

Welcoming the role that women's movements have played in drawing increasing attention to the nature, severity and magnitude of the problem of violence against women.

Alarmed that women's opportunities to achieve legal, social, political and economic equality in society are limited, inter alia, by continuing and endemic violence,

Convinced that in the light of the above there is a need for a clear and comprehensive definition of violence against women, a clear statement of the rights to be applied to ensure the elimination of violence against women in all its forms, a commitment by States in respect of their responsibilities, and a commitment by the international community at large towards the elimination of violence against women,

Solemnly proclaims the following Declaration on the Elimination of Violence against Women and urges that every effort be made so that it becomes generally known and respected:

\section{Article 1}

For the purposes of this Declaration, the term 'violence against women' means any act of gender-based violence that results in, or is likely to result in, physical, sexual or psychological harm or suffering to women, including threats of such acts, coercion or arbitrary deprivation of liberty, whether occurring in public or in private life.

\section{Article 2}

Violence against women shall be understood to encompass, but not be limited to, the following:

a) Physical, sexual and psychological violence occurring in the family, including battering, sexual abuse of female children in the household, dowry-related violence, marital rape, female genital mutilation and other traditional practices harmful to women, non-spousal violence and violence related to exploitation;

b) Physical, sexual and psychological violence occurring within the general community, including rape. sexual abuse, sexual harassment and intimidation at work, in educational institutions and elsewhere, trafficking in women and forced prostitution;

c) Physical, sexual and psychological violence perpetrated or condoned by the State, wherever it occurs.

\section{Article 3}

Women are entitled to the equal enjoyment and protection of all human rights and fundamental freedoms in the political, economic, social, cultural, civil or any other field. These rights include, inter alia:

a) The right to life;

b) The right to equality;

c) The right to liberty and security of person;"

' Universal Declaration of Human Rights, Article 3; and International Covenant on Civil and Political Rights, Article 6.

${ }^{8}$ International Covenant on Civil and Political Rights, Article 26.

${ }^{9}$ Universal Declaration of Human Rights, Article 3; and International Covenant on Civil and Political Rights, Article 9. 
d) The right to equal protection under the law; 10

e) The right to be free from all forms of discrimination:"

f) The right to the highest standard attainable of physical and mental health;:

g) The right to just and favourable conditions of work; ${ }^{13}$

h) The right not to be subjected to torture, or other cruel, inhuman or degrading treatment or punishment. ${ }^{14}$

\section{Article 4}

States should condemn violence against women and should not invoke any custom, tradition or religious consideration to avoid their obligations with respect to its elimination. States should pursue by all appropriate means and without delay a policy of eliminating violence against women and, to this end, should:

a) Consider, where they have not yet done so, ratifying or acceding to the Convention on the Elimination of All Forms of Discrimination against Women or withdrawing reservations to that Convention;

b) Refrain from engaging in violence against women;

c) Exercise due diligence to prevent, investigate and, in accordance with national legislation, punish acts of violence against women, whether those acts are perpetrated by the State or by private persons;

d) Develop penal, civil, labour and administrative sanctions in domestic legislation to punish and redress the wrongs caused to women who are subjected to violence; women who are subjected to violence should be provided with access to the mechanisms of justice and, as provided for by national legislation, to just and effective remedies for the harm that they have suffered; States should also inform women of their rights in seeking redress through such mechanisms;

e) Consider the possibility of developing national plans of action to promote the protection of women against any form of violence, or to include provisions for this purpose in plans already existing, taking into account, as appropriate, such co-operation as can be provided by non-governmental organisations, particularly those concerned with this subject:

t) Develop, in a comprehensive way, preventive approaches and all those measures of a legal, political, administrative and cultural namre that promote the protection of women against any form of violence, and ensure that the re-victimisation of women does not occur because of gender insensitive laws, enforcement practices or other interventions;

g) Work to ensure, to the maximum extent feasible in the light of their available resources and, where needed, within the framework of international co-operation, that women subjected to violence and, where appropriate, their children have specialised assistance, such as rehabilitation, assistance in child care and maintenance, treatment, counselling, health and social services, facilities and programmes; as well as support structures, and should take all other appropriate measures to promote their safety and physical and psychological rehabilitation;

h) Include in government budgets adequate resources for their activities related to the elimination of violence against women:

i) Take measures to ensure that law enforcement officers and public officials responsible for implementing policies to prevent, investigate and punish violence against women receive training to sensitise them to the needs of women;

j) Adopt all appropriate measures, especially in the field of education, to modify the social and cultural patterns of conduct of men and women and to eliminate prejudices, customary practices and all other practices based on the idea of the inferiority or superiority of either of the sexes and on stereotyped roles

${ }^{10}$ Intemational Covenant on Civil and Political Rights, Article 26.

"International Covenant on Civil and Political Rights, Article 26.

12 Intemational Covenant on Economic, Social and Cultural Rights. Article 12.

${ }^{13}$ Universal Declaration of Human Rights, Article 23; and International Covenant on Economic, Social and Cultural Rights, Articles 6 and 7.

14 Universal Declaration of Human Rights, Article 5; International Covenant on Civil and Political Rights, Article 7; and Convention against Torture and Other Cruel, Inhuman or Degrading Treatment or Punishment. 
for men and women;

k) Promote research, collect data and compile statistics, especially conceming domestic violence, relating to the prevalence of different forms of violence against women and encourage research on the causes, nature, seriousness and consequences of violence against women and on the effectiveness of measures implemented to prevent and redress violence against women; those statistics and findings of the research will be made public;

1) Adopt measures directed to the elimination of violence against women who are especially vulnerable to violence;

m) Include, in submitting reports as required under relevant human rights instruments of the United Nations, information pertaining to violence against women and measures taken to implement the present Declaration;

n) Encourage the development of appropriate guidelines to assist in the implementation of the principles set forth in the present Declaration;

o) Recognise the important role of the women's movement and non-governmental organisations world wide in raising awareness and alleviating the problem of violence against women;

p) Facilitate and enhance the work of the women's movement and non-governmental organisations and cooperate with them at local, national and regional levels;

q) Encourage intergovernmental regional organisations of which they are members to include the elimination of violence against women in their programmes, as appropriate.

\section{Article 5}

The organs and specialised agencies of the United Nations system should, within their respective fields of competence, contribute to the recognition and realisation of the rights and the principles set forth in the present Declaration, and to this end should, inter alia:

a) Foster intemational and regional co-operation with a view to defining regional strategies for combating violence, exchanging experiences and financing programmes relating to the elimination of violence against women;

b) Promote meetings and seminars with the aim of creating and raising awareness among all persons the issue of the elimination of violence against women;

c) Foster co-ordination and exchange within the United Nations system between human rights treaty bodies to address the matter effectively;

d) Include in analyses prepared by organisations and bodies of the United Nations system of social trends and problems, such as the periodic reports on the world social situation, examination of trends in violence against women;

e) Encourage co-ordination between organisations and bodies of the United Nations system to incorporate the issue of violence against women into ongoing programmes, especially with reference to groups of women particularly vilnerable to violence;

f) Promote the formulation of guidelines or manuals relating to violence against women, taking into account the measures mentioned herein;

g) Consider the issue of the elimination of violence against women, as appropriate, in fulfilling their mandates with respect to the implementation of human rights instruments;

h) Co-operate with non-governmental organisations in addressing violence against women.

\section{Article 6}

Nothing in the present Declaration shall affect any provision that is more conducive to the elimination of violence against women that may be contained in the legislation of a State or in any international convention, treaty or other instrument in force in a State. 
for men and women;

k) Promote research, collect data and compile statistics, especially concerning domestic violence, relating to the prevalence of different forms of violence against women and encourage research on the causes, nature, seriousness and consequences of violence against women and on the effectiveness of measures implemented to prevent and redress violence against women; those statistics and findings of the research will be made public;

1) Adopt measures directed to the elimination of violence against women who are especially vulnerable to violence;

m) Include, in submitting reports as required under relevant human rights instruments of the United Nations, information pertaining to violence against women and measures taken to implement the present Declaration;

n) Encourage the development of appropriate guidelines to assist in the implementation of the principles set forth in the present Declaration;

o) Recognise the important role of the women's movement and non-governmental organisations world wide in raising awareness and alleviating the problem of violence against women;

p) Facilitate and enhance the work of the women's movement and non-governmental organisations and cooperate with them at local, national and regional levels;

q) Encourage intergovernmental regional organisations of which they are members to include the elimination of violence against women in their programmes, as appropriate.

\section{Article 5}

The organs and specialised agencies of the United Nations system should, within their respective fields of competence, contribute to the recognition and realisation of the rights and the principles set forth in the present Declaration, and to this end should, inter alia:

a) Foster international and regional co-operation with a view to defining regional strategies for combating violence, exchanging experiences and financing programmes relating to the elimination of violence against women;

b) Promote meetings and seminars with the aim of creating and raising awareness among all persons the issue of the elimination of violence against women;

c) Foster co-ordination and exchange within the United Nations system between human rights treaty bodies to address the matter effectively;

d) Include in analyses prepared by organisations and bodies of the United Nations system of social trends and problems, such as the periodic reports on the world social situation, examination of trends in violence against women;

e) Encourage co-ordination between organisations and bodies of the United Nations system to incorporate the issue of violence against women into ongoing programmes, especially with reference to groups of women particularly vulnerable to violence;

f) Promote the formulation of guidelines or manuals relating to violence against women, taking into account the measures mentioned berein;

g) Consider the issue of the elimination of violence against women, as appropriate, in fulfilling their mandates with respect to the implementation of human rights instruments;

h) Co-operate with non-governmental organisations in addressing violence against women.

\section{Article 6}

Nothing in the present Declaration shall affect any provision that is more conducive to the elimination of violence against women that may be contained in the legislation of a State or in any international convention, treaty or other instrument in force in a State. 


\section{Convention on the Elimination of All Forms of Discrimination against Women}

\section{Text}

\section{PREAMBLE}

The States Parties to the present Convention,

Noting that the Charter of the United Nations reaffirms faith in fundamental human rights, in the dignity and worth of the human person and in the equal rights of men and women,

Noting that the Universal Declaration of Human Rights affirms the principle of the inadmissibility of discrimination and proclaims that all human beings are born free and equal in dignity and rights and that everyone is entitled to all the rights and freedoms set forth therein, without distinction of any kind, including distinction based on sex,

Noting that the States Parties to the International Covenants on Human Rights have the obligation to ensure the equal right of men and women to enjoy all economic, social, cultural, civil and political rights,

Considering the international conventions concluded under the auspices of the United Nations and the specialized agencies promoting equality of rights of men and women,

Noting also the resolutions, declarations and recommendations adopted by the United Nations and the specialized agencies promoting equality of rights of men and women,

Concerned, however, that despite these various instruments extensive discrimination against women continues to exist,

Recalling that discrimination against women violates the principles of equality of rights and respect for human dignity, is an obstacle to the participation of women, on equal terms with men, in the political, social, economic and cultural life of their countries, hampers the growth of the prosperity of society and the family and makes more difficult the full development of the potentialities of women in the service of their countries and of humanity,

Concerned that in situations of poverty women have the least access to food, health, education, training and opportunities for employment and other needs,

Convinced that the establishment of the new international economic order based on equity and justice will contribute significantly towards the promotion of equality between men and women,

\section{Unofficial Summary of Main Provisions}

\section{PREAMBLE}

The Preamble links women's rights to human rights.

- The preamble of the CEDAW Convention recalls that the basic principles of the United Nations include faith in fundamental human rights, in the dignity of the human person, and in the equal rights of men and women.

- It reminds the international community that all human rights treaties concluded by the United Nations and its specialized agencies entitle men and women to enjoy equally the rights they enshrine.

- It notes that specific instruments have been adopted to promote the principle of equality between men and women.

- It acknowledges, however, that extensive discrimination against women continues to exist, and emphasizes that this discrimination violates the principles of equality of rights and respect for human dignity.

- It further states that discriminatory practices impede the participation of women in all aspects of the life of their countries on an equal basis with men, which hampers the increased prosperity of their society and families. 
Emphasizing that the eradication of apartheid, of all forms of racism, racial discrimination, colonialism, neo-colonialism, aggression, foreign occupation and domination and interference in the internal affairs of States is essential to the full enjoyment of the rights of men and women,

Affirming that the strengthening of international peace and security, relaxation of international tension, mutual co-operation among all States irrespective of their social and economic systems, general and complete disarmament, and in particular nuclear disarmament under strict and effective international control, the affirmation of the principles of justice, equality and mutual benefit in relations among countries and the realization of the right of peoples under alien and colonial domination and foreign occupation to self-determination and independence, as well as respect for national sovereignty and territorial integrity, will promote social progress and development as a consequence will contribute to the attainment of full equality between men and women,

Convinced that the full and complete development of a country, the welfare of the world and the cause of peace require the maximum participation of women on equal terms with men in all fields,

Bearing in mind the great contribution of women to the welfare of the family and to the development of society, so far not fully recognized, the social significance of maternity and the role of both parents in the family and in the upbringing of children, and aware that the role of women in procreation should not be a basis of discrimination but the upbringing of children requires a sharing of responsibility between men and women and society as a whole,

Aware that a change in the traditional role of men as well as the role of women in society and in the family is needed to achieve full equality between men and women,

Determined to implement the principles set forth in the Declaration on the Elimination of Discrimination against Women and, for that purpose, to adopt the measures required for the elimination of such discrimination in all its forms and manifestations,

Have agreed on the following:

\section{PART I}

\section{Article 1}

For the purposes of the present convention, the term "discrimination against women" shall mean any distinction, exclusion or restriction made on the basis of sex which has the effect or purpose of impairing or nullifying

\section{CEDAW defines discrimination against women.}

- The Convention concerns discrimination against women rather than discrimination on the basis of sex. 
the recognition, enjoyment or exercise by women, irrespective of their marital status, on a basis of equality of men and women, of human rights and fundamental freedoms in the political, economic, social, cultural, civil or any other field.

\section{Article 2}

States Parties condemn discrimination against women in all its forms, agree to pursue by all appropriate means and without delay a policy of eliminating discrimination against women and, to this end, undertake

(a) To embody the principle of the equality of men and women in their national constitutions or other appropriate legislation if not yet incorporated therein and to ensure, through law and other appropriate means, the practical realization of this principle;

(b) To adopt appropriate legislative and other measures, including sanctions where appropriate, prohibiting all discrimination against women;

(c) To establish legal protection of the rights of women on an equal basis with men and to ensure through competent national tribunals and other public institutions the effective protection of women against any act of discrimination;

(d) To refrain from engaging in any act or practice of discrimination against women and to ensure that public authorities and institutions shall act in conformity with this obligation;

(e) To take all appropriate measures to eliminate discrimination against women by any person, organization or enterprise;

(f) To take all appropriate measures, including legislation, to modify or abolish existing laws, regulations, customs and practices which constitute discrimination against women;

(g) To repeal all national penal provisions which constitute discrimination against women.

\section{Article 3}

States parties shall take in all fields, in particular in the political, social, economic and cultural fields, all appropriate measures, including legislation, to ensure the full development and advancement of women, for the purpose of guaranteeing them the exercise and enjoyment of human rights and fundamental freedoms on a basis of equality with men.

\section{Article 4}

1. Adoption by States Parties of temporary special measures aimed at accelerating de facto equality between men and women shall not be considered discrimina-
- Discrimination against women includes any distinction, exclusion or restriction made on the basis of sex that affects women's enjoyment of political, economic, social, cultural, civil or any other rights, irrespective of marital status, on an equal basis with men.

\section{It obliges states to take concrete steps to eliminate discrimination against women.}

- States that ratify CEDAW are obliged not only to condemn all forms of discrimination against women, but also to implement various measures towards its elimination.

- Ratifying states must also embody the principle of equality in their national constitutions or other laws and adopt legislative and other measures, including sanctions, as appropriate.

- States must establish legal protection against discrimination through national tribunals and other public institutions.

- Public authorities and institutions in ratifying states are to refrain from discriminatory practices.

- States must modify or abolish existing laws, customs and practices that discriminate against women, as well as penal provisions that amount to discrimination against women.

- The state must do all it can to ensure the full development and advancement of women so that they can exercise and enjoy human rights and fundamental freedoms equally with men.

\section{Unlike other human rights treaties, CEDAW does not solely address actions by the state or its agencies.}

- States are obliged to take all appropriate measures to eliminate discrimination against women by any person, organization or enterprise.

- This provision makes CEDAW unique, because international human rights treaties are usually limited to the conduct of the state or its agencies.

\section{CEDAW allows for temporary affirmative action measures.}

- States are entitled to adopt temporary special measures to accelerate equality for women. 
tion as defined in the present Convention, but shall in no way entail as a consequence the maintenance of unequal or separate standards; these measures shall be discontinued when the objectives of equality of opportunity and treatment have been achieved.

2. Adoption by States Parties of special measures, including those measures contained in the present Convention, aimed at protecting maternity shall not be considered discriminatory.

\section{Article 5}

States Parties shall take all appropriate measures:

(a) To modify the social and cultural patterns of conduct of men and women, with a view to achieving the elimination of prejudices and customary and all other practices which are based on the idea of the inferiority or the superiority of either of the sexes or on stereotyped roles for men and women;

(b) To ensure that family education includes a proper understanding of maternity as a social function and the recognition of the common responsibility of men and women in the upbringing and development of their children, it being understood that the interest of the children is the primordial consideration in all cases.

\section{Article 6}

States Parties shall take all appropriate measures, including legislation, to suppress all forms of traffic in women and exploitation of prostitution of women.

\section{PART II}

\section{Article 7}

States Parties shall take all appropriate measures to eliminate discrimination against women in the political and public life of the country and, in particular, shall ensure to women, on equal terms with men, the right:

(a) To vote in all elections and public referenda and to be eligible for election to all publicly elected bodies;

(b) To participate in the formulation of goveinment policy and the implementation thereof and to hold public office and perform all public functions at all levels of government;

(c) To participate in non-governmental organizations and associations concerned with the public and political life of the country.
- This allows for the introduction of affirmative action or positive discrimination until the objective of equality has been achieved.

- In any event, special measures aimed at the protection of maternity will not be regarded as discriminatory.

\section{It recognizes the role of culture and tradition, and calls upon states to eliminate sex role stereotyping.}

- The Convention recognizes the influence of culture and tradition in restricting women's enjoyment of rights. It provides, therefore, that states are to take appropriate measures to eliminate sex role stereotyping and practices that stem from a concept of the inferiority or superiority of one sex over the other.

- Family education should teach the common role of both men and women in the upbringing of children, which must, in all cases, be governed by their best interest of the children.

\section{CEDAW requires states to suppress all forms of traffic in women and exploitation of prostitution.}

- States must take all measures, including legislation, to suppress all forms of traffic in women and exploitation of prostitution.

- The Convention defines traffic in women broadly to include sexual slavery, generally and by the military, the deception of migrant women, and "mail order" and false marriages.

- States are obliged to take measures to prevent women and girls from resorting to prostitution for survival.

\section{The Convention addresses discrimina- tion in political and public life.}

- States must eliminate discrimination against women in the political and public life of the country.

- Women must be entitled to vote, to be eligible for election, to participate in the formulation of government policy and to hold office on an equal basis with men.

- Women must be eligible to participate in nongovernmental and other associations, including political parties, trade unions and professional associations, on an equal basis with men. 


\section{Article 8}

States Parties shall take all appropriate measures to ensure to women, on equal terms with men and without any discrimination, the opportunity to represent their Governments at the international level and to participate in the work of international organizations.

\section{Article 9}

1. States Parties shall grant women equal rights with men to acquire, change or retain their nationality. They shall ensure in particular that neither marriage to an alien nor change of nationality by the husband during marriage shall automatically change the nationality of the wife, render her stateless or force upon her the nationality of the husband.

2. States Parties shall grant women equal rights with men with respect to the nationality of their children.

\section{PART III}

\section{Article 10}

States Parties shall take all appropriate measures to eliminate discrimination against women in order to ensure to them equal rights with men in the field of education and in particular to ensure, on a basis of equality of men and women:

(a)The same conditions for career and vocational guidance, for access to studies and for the achievement of diplomas in educational establishments of all categories in rural as well as in urban areas; this equality shall be ensured in pre-school, general, technical, professional and higher technical education, as well as in all types of vocational training;

(b)Access to the same curricula, the same examinations, teaching staff with qualifications of the same standard and school premises and equipment of the same quality;

(c) The elimination of any stereotyped concept of the roles of men and women at all levels and in all forms of education by encouraging coeducation and other types of education which will help to achieve this aim and, in particular, by the revision of textbooks school programmes and the adaptation of teaching methods;

(d)The same opportunities to benefit from scholarships and other study grants;

(e)The same opportunities for access to programmes of continuing education, including adult and functional literacy programmes, particularly those aimed at reducing, at the earliest possible time, any gap in education existing between men and women;
- Women must be given equal opportunity to represen their governments and to participate in the work of international organizations, such as the UN and its specialized agencies.

\section{CEDAW addresses the rights of women and their children in relation to nationality.}

- Women must be granted equal rights with men to acquire, change or retain their nationality.

- Women's nationality should not be automatically changed, nor should they be forced to change their nationality nor be rendered stateless if they marry ar - alien or if their husband; change their nationality.

- Women shall also have equal rights with men where the nationality of their children is concerned.

\section{In obliging states to eliminate discrim- ination in education, CEDAW deals nol only with access to education, but alsi with its substance.}

- Discrimination against women in education is to be eliminated.

- Women and girls should receive career and vocational guidance at all levels, in rural as well as urbar. areas, access to curricula, examinations, teaching staff, premises and equipment on the same basis. as men and boys.

- Stereotyping shall be eliminated, by the active encouragement of co-education and particularly through the revision of textbooks and school programmes and adaptation of teaching methods.

- Women shall have the same opportunities to benefil from scholarships and other study grants and for access to programmes of continuing education, including adult and functional literacy programmes.

- Efforts are to be made to reduce the numbers of female students who drop out and to provide programmes for those who have left school prematurely

- The same opportunities to participate in sports and physical education is to be provided as well as access to specific educational information to ensure the health and well-being of families. 
(f) The reduction of female student drop-out rates and the organization of programmes for girls and women who have left school prematurely;

(g) The same opportunities to participate actively in sports and physical education;

(h) Access to specific educational information to help to ensure the health and well-being of families, including information and advice on family planning.

\section{Article 11}

1. States Parties shall take all appropriate measures to eliminate discrimination against women in the field of employment in order to ensure, on a basis of equality of men and women, the same rights, in particular:

(a) The right to work as an inalienable right of all human beings;

(b) The right to the same employment opportunities, including the application of the same criteria for selection in matters of employment;

(c) The right to free choice of profession and employment, the right to promotion, job security and all benefits and conditions of service and the right to

receive vocational and retraining, including apprenticeships, advanced vocational training and recurrent training;

(d) The right to equal remuneration, including benefits, and to equal treatment in respect of work of equal value, as well as equality of treatment in the evaluation of the quality of work;

(e) The right to social security, particularly in cases of retirement, unemployment, sickness, invalidity and old age and other incapacity to work, as well as the right to paid leave;

(f) The right to protection of health and to safety in working conditions, including the safeguarding of the function of reproduction.

2. In order to prevent discrimination against women on the grounds of marriage or maternity and to ensure their effective right to work, States Parties shall take appropriate measures:

(a) To prohibit, subject to the imposition of sanctions, dismissal on the grounds of pregnancy or of maternity leave and discrimination in dismissals on the basis of marital status;

(b) To introduce maternity leave with pay or with comparable social benefits without loss of former employment, seniority or social allowances;

(c) To encourage the provision of the necessary supporting social services to enable parents to

\section{It recognizes the right to work as a human right.}

- Women are to be ensured equal rights with men in employment.

- The right to work is declared to be an inalienable right of all human beings.

- Women have the same rights as men to free choice of profession and employment, job security, benefits, and vocational training and retraining.

- States must ensure the right to equal pay and equal treatment for work of equal value, as well as equal social security benefits and paid leave.

- Women shall have the right to protection of health and safety at work, which must include safeguarding reproduction.

- Special protection shall be provided for women during pregnancy, but any protective legislation with regard to employment shall be reviewed periodically and revised, repealed or extended as necessary.

- States must prohibit discrimination on the grounds of pregnancy, maternity leave or marital status; they must introduce paid maternity leave, without loss of employment, seniority or social allowances.

- States should encourage the provision of social allowances and support services, such as child-care facilities, that enable parents to combine family life, employment and participation in public life. 
combine family obligations with work responsibilities and participation in public life, in particular through promoting the establishment and development of a network of child-care facilities;

(d) To provide special protection to women during pregnancy in types of work proved to be harmful to them.

3. Protective legislation relating to matters covered in this article shall be reviewed periodically in the light of scientific and technological knowledge and shall be revised, repealed or extended as necessary.

\section{Article 12}

1. States Parties shall take all appropriate measures to eliminate discrimination against women in the field of health care in order to ensure, on a basis of equality of men and women, access to health care services, including those related to family planning.

2. Notwithstanding the provisions of paragraph 1 of this article, States Parties shall ensure to women appropriate services in connection with pregnancy, confinement and the post-natal period, granting free services where necessary, as well as adequate nutrition during pregnancy and lactation.

\section{Article 13}

1. States Parties shall take all appropriate measures to eliminate discrimination against women in other. areas of economic and social life in order to ensure, on a basis of equality of men and women, the same rights, in particular:

(a) The right to family benefits;

(b) The right to bank loans, mortgages and other forms of financial credit;

(c) The right to participate in recreational activities, sports and all aspects of cultural life.

\section{Article 14}

1. States Parties shall take into account the particular problems faced by rural women and the significant roles which rural women play in the economic survival of their families, including their work in the non-monetized sectors of the economy, and shall take all appropriate measures to ensure the application of the provisions of this Convention to women in rural areas.

2. States Parties shall take all appropriate measures to eliminate discrimination against women in rural areas in order to ensure, on a basis of equality of men and women, that they participate in and benefit from rural development and, in particular, shall ensure to such

\section{CEDAW is the only international treaty whose provisions cover family planning.}

- The first of three provisions, which concern reproductive choice, constitute the only international treaty obligations relating to family planning.

- States agree to provide educational information and advice on family planning.

- States are required to provide women and men equal access to health care and family planning.

- Women shall also be ensured pregnancy, confinement and post-natal services, free of charge if necessary, and adequate nutrition during pregnancy and lactation.

\section{The Convention addresses discrimina- tion in economic, social, and cultural life.}

- It requires states to eliminate discrimination against women in areas of economic life not touched on by other provisions of the Convention.

- In particular, women are to be granted the same rights as men to family benefits, bank loans, mortgages, and other forms of family credit.

- Women are to have the same rights as men to participate in recreational activities, sports, and all aspects of cultural life.

- CEDAW is unusual in obliging states to eliminate discrimination in the areas of financial services and recreation: it imposes on states the duty to regulate the activities of third parties that, in many cases, are not state agencies.

\section{It addresses, in particular, discrimina- tion against rural women.}

- States undertake to eliminate discrimination against women in rural areas so that they may participate and benefit from rural development equally with men. 
women the right:

(a) To participate in the elaboration and implementation of development planning at all levels;

(b) To have access to adequate health care facilities, including information, counselling and services in family planning;

(c) To benefit directly from social security programmes;

(d) To obtain all types of training and education, formal and non-formal, including that relating to functional literacy, as well as, inter alia, the benefit of all community and extension services, in order to increase their technical proficiency;

(e) To organize self-help groups and co-operatives in order to obtain equal access to economic opportunities through employment or self-employment;

(f) To participate in all community activities;

(g) To have access to agricultural credit and loans, marketing facilities, appropriate technology and equal treatment in land and agrarian reform as well as in land resettlement schemes;

(h) To enjoy adequate living conditions, particularly in relation to housing, sanitation, electricity and water supply, transport and communications.

\section{PART IV}

\section{Article 15}

1. States Parties shall accord to women equality with men before the law.

2. States Parties shall accord to women, in civil matters, a legal capacity identical to that of men and the same opportunities to exercise that capacity. In particular, they shall give women equal rights to conclude contracts and to administer property and shall treat them equally in all states of procedure in courts and tribunals.

3. States Parties agree that all contracts and all other private instruments of any kind with a legal effect which is directed at restricting the legal capacity of women shall be deemed null and void.

4. States Parties shall accord to men and women the same rights with regard to the law relating to the movement of persons and the freedom to choose their residence and domicile.

\section{Article 16}

1. States Parties shall take all appropriate measures to eliminate discrimination against women in all matters relating to marriage and family relations and in particular
- Specifically rural women are ensured the equal right to participate in development planning, to have access to health care facilities, to benefit from social security programmes, to obtain formal and nonformal education and training, to organize self-help groups and co-operatives in addition to participating in community activities.

- Rural women are ensured equal rights to adequate living conditions, including housing, sanitation, electricity, water supply, transportation, and communications.

\section{CEDAW guarantees equality before the law.}

- Women are to be accorded the same legal status as men in civil matters.

- Women shall have the same right to enter into contracts, administer property and receive equal treatment in courts and tribunals.

- Any contract or private agreement that limits the legal capacity of women shall be null and void.

- Women are ensured freedom of movement and the right to choose their residence and domicile on an equal basis with men.

\section{"Equality before the law" includes marriage and family law.}

- States shall ensure equality in marriage and family relations. 
shall ensure, on a basis of equality of men and women:

(a) The same right to enter into marriage;

(b) The same right freely to choose a spouse and to enter into marriage only with their free and full consent;

(c) The same rights and responsibilities during marriage and at its dissolution;

(d) The same rights and responsibilities as parents, irrespective of their marital status, in matters relating to their children; in all cases the interests of the children shall be paramount;

(e) The same rights to decide freely and responsibly on the number and spacing of their children and to have access to the information, education and means to enable them to exercise these rights;

(f) The same rights and responsibilities with regard to guardianship, wardship, trusteeship and adoption of children, or similar institutions where these concepts exist in national legislation; in all cases the interests of the children shall be paramount;

(g) The personal rights as husband and wife, including the right to choose a family name, a profession and an occupation;

(h) The same rights for both spouses in respect of the ownership, acquisition, management, administration, enjoyment and disposition of property, whether free of charge or for a valuable consideration.

2. The betrothal and the marriage of a child shall have no legal effect, and all necessary action, including legislation, shall be taken to specify a minimum age for marriage and to make the registration of marriages in an official registry compulsory.

\section{PART V}

\section{Article 17}

1. For the purpose of considering the progress made in the implementation of the present Convention, there shall be established a Committee on the Elimination of Discrimination against Women (hereinafter referred to as the Committee) consisting, at the time of entry into force of the Convention, of eighteen and, after ratification of or accession to the Convention by the thirty-fifth State Party, of twenty-three experts of high moral standing and competence in the field covered by the Convention. The experts shall be elected by States Parties from among their nationals and shall serve in their personal capacity, consideration being given to equitable geographical distribution and to the
- Women shall have the same right to enter marriage as men on the basis of free and full consent and have equal freedom to choose their spouse.

- States are obliged to set a minimum age for, and registration of, all marriages. The betrothal of a child shall have no legal force.

- Women shall be accorded equal rights with men during marriage and at its dissolution.

- Vomen shall have equal right to their children and in the number and spacing of their children, as well as the access to information and means to make decisions in this area. They shall have the same rights as men in guardianship, wardship, and adoption.

- Women will also have the same rights as their husbands in choosing a family name, profession or occupation and in ownership, management, and disposal of property.

\section{CEDAW creates a 23-member commit- tee to implement its provisions and monitor compliance.}

- The implementation of the Convention is monitored by the Committee on the Elimination of Discrimination against Women.

- The CEDAW Committee is composed of 23 experts of high moral standing and competence in the fields covered by the Convention.

- Committee members are nominated by their governments, and are elected by secret ballot by state parties to the Convention. In this election, consideration is given to equitable geographical distribution, 


\section{Article 18}

1. States Parties undertake to submit to the SecretaryGeneral of the United Nations, for consideration by the Committee, a report on the legislative, judicial,

' administrative or other measures which they have adopted to give effect to the provisions of the present Convention and on the progress made in this respect:

(a) Within a year after the entry into force for the State concerned; and

(b) Thereafter at least every four years and further whenever the Committee so requests.

2. Reports may indicate factors and difficulties affecting the degree of fulfillment of obligations under the present Convention.

\section{Article 19}

1.The Committee shall adopt its own rules of procedure.

2. The Committee shall elect its officers for a term of two years

\section{Article 20}

1. The Committee shall normally meet for a period of not more than two weeks annually in order to consider the reports submitted in accordance with article 18 of the present Convention.

2. The meetings of the Committee shall normally be held at United Nations Headquarters or at any other convenient place as determined by the Committee.

\section{Article 21}

1. The Committee shall, through the Economic and Social Council, report annually to the General Assembly of the United Nations on its activities and may make suggestions and general recommendations based on the examination of reports and information received from the States Parties. Such suggestions and general recommendations shall be included in the report of the Committee together with comments, if any, from States Parties.

2. The Secretary-General shall transmit the reports of the Committee to the Commission on the States of Women for its information.

\section{Article 22}

The specialized agencies shall be entitled to be represented at the consideration of the implementation of such provisions of the present Convention as fall within the scope of their activities. The Committee may invite the specialized agencies to submit reports on the imple-

\section{States are required to report to the Committee on their efforts to meet CEDAW's goals.}

- Within the first year of ratification or accession, and every four years thereafter, states are expected to submit a national report to the Committee, indicating the measures they have adopted to carry out the provisions of the Convention.

- During its annual session, the Committee shall discuss these reports with the Government representatives and explore with them areas for further action by the specific country.

- The Committee also makes general recommendations to the states parties on matters concerning the elimination of discrimination against women. 
mentation of the Convention in areas falling within the scope of their activities.

\section{PART VI}

\section{Article 23}

Nothing in this Convention shall affect any provisions that are more conducive to the achievement of equality between men and women which may be contained:

(a) In the legislation of a State Party; or

(b) In any other international convention, treaty or agreement in force for that State.

\section{Article 24}

States Parties undertake to adopt all necessary measures at the national level aimed at achieving the full realization of the rights recognized in the present Convention.

\section{Article 25}

1. The present Convention shall be open for signature by all States.

2. The Secretary-General of the United Nations is designated as the depository of the present Convention.

3 . The present Convention is subject to ratification. Instruments of ratification shall be deposited with the Secretary-General of the United Nations.

4. The present Convention shall be open to accession by all States. Accession shall be effected by the deposit of an instrument of accession with the Secretary-General of the United Nations.

\section{Article 26}

1. A request for the revision of the present Convention may be made at any time by any State Party by means of a notification in writing addressed to the Secretary-General of the United Nations.

2. The General Assembly of the United Nations shall decide upon the steps, if any, to be taken in respect of such a request.

\section{Article 27}

1. The present Convention shall enter into force on the thirtieth day after the date of deposit with the Secretary-General of the United Nations of the twentieth instrument of ratification or accession.

2. For each State ratifying the present Convention or acceding to it after the deposit of the twentieth instru- 
ment of ratification or accession, the Convention shall enter into force on the thirtieth day after the date of the deposit of its own instrument of ratification or accession

\section{Article 28}

1. The Secretary-General of the United Nations shall receive and circulate to all States the text of reservations made by States at the time of ratification or accession.

2. A reservation incompatible with the object and purpose of the present Convention shall not be permitted.

3. Reservations may be withdrawn at any time by notification to this effect addressed to the SecretaryGeneral of the United Nations, who shall then inform all States thereof. Such notification shall take effect on the date on which it is received

\section{Article 29}

1. Any dispute between two or more States Parties concerning the interpretation or application of the present Convention which is not settled by negotiation shall, at the request of one them, be submitted to arbitration. If within six months from the date of the request for arbitration the parties are unable to agree on the organization of the arbitration, any one of those parties may refer the dispute to the International Court of Justice by request in conformity with the Statute of the Court.

2. Each State Party may at the time of signature or ratification of this Convention or accession thereto declare that it does not consider itself bound by paragraph 1 of this article. The other States Parties shall not be bound by that paragraph with respect to any State Party which has made such a reservation.

3. Any State Party which has made a reservation in accordance with paragraph 2 of this article may at any time withdraw that reservation by notification to the Secretary-General of the United Nations.

\section{Article 30}

The present Convention, the Arabic, Chinese, English, French, Russian and Spanish texts of which are equally authentic, shall be deposited with the Secretary-General of the United Nations.

\section{States are entitled to ratify or accede to the Convention with reservations.}

- Reservations may not be incompatible with the object and purpose of the treaty.

- Reservations may be withdrawn at any time.

- Any dispute between states regarding the interpretation of the Convention may be submitted to arbitration or, if the terms of the arbitration cannot be agreed upon within a six-month period, to the International Court of Justice. 


\section{CEDAW and Women's Human Rights}

One of the characteristics of the politics of the late twentieth century is respect for the concept of human rights - one of the few moral visions ascribed to by people and nations all over the world. There is no consensus on the scope of the vision; but the vision itself resonates deeply in all of us. The belief in fundamental human rights is not only one of the few goals generally accepted throughout the international community and by most national governments, it also forms the foundation of the United Nations. A measure of the concept's pivotal place in politics today is the number of international organizations whose very raison d'etre is the achievement of a world order and an individual condition rooted in human rights.

\section{Vision and Reality}

Universality is a key element of the human rights vision. Human rights and the mechanisms designed to actualize them are supposed to be equally available to men and women. There is, however, a sizable gap between the vision and the reality. Since the beginning of this decade, there has been increasing recognition that the international human rights movement has benefitted men more than women.

As a result, some activists and organizations, mainly NGOs, have worked to redefine the meaning of human rights to reflect the specific experiences of women at all stages of their lives, from birth through adulthood. Their work has brought about remarkable advances in women's human rights:

- In June 1993, the United Nations World Conference on Human Rights significantly expanded the international human rights agenda to include gender-specific violations. The Vienna Declaration and Programme of Action, the final conference document, cited examples of gender-specific abuse as human rights violations and called for the integration of efforts to ensure women's human rights across the full range of United Nations activities.

- In December 1993, the United Nations General Assembly adopted the Declaration Against Violence Against Women. This Declaration elaborated the definition of gender-based violence against women, and defined it as a critical human rights issue.

- In March 1994, the United Nations Commission on Human Rights, agreed to appoint a Special Rapporteur on violence against women, its causes and consequences, and to integrate the rights of women into the human rights mechanisms of the United Nations.

These breakthroughs have begun to reclaim the vision of human rights for women and to reverse a pattern of neglect of women's human rights by the international community, including the international human rights community and the United Nations. These advances have shown both the potential of the human rights framework for improving the status and condition of women and the potential of a gender perspective for strengthening the human rights framework.

\section{Women's Human Rights in Historical Perspective}

The international human rights agenda has expanded dramatically since the adoption of the Universal Declaration of Human Rights. An extensive body of international standards has been adopted and a wide range of institutions and procedures has been established to monitor and secure implementation of these rights. 
The United Nations and the International Labour Organization (ILO) have been responsible for much of this standard setting. However, a number of international agreements protecting women's rights predated these organisations:

- The 1902 Hague Conventions dealt with the conflicts of national laws concerning marriage, divorce and the guardianship of minors.

- International agreements adopted In 1904, 1910, 1921 and 1933 aimed at combatting trafficking in women.

- The Covenant of the League of Nations called for humane conditions for all, irrespective of sex, and urged the suppression of trafficking in women. It specifically provided that employment connected with the League would be open equally to men and women.

Treaties elaborating particular rights for women, including the 1952 Convention on the Political Rights of Women and the 1957 Convention on the Nationality of Married Women, were formulated after the establishment of the United Nations. Treaties of this nature soon fell out of political fashion; the prevailing view held that "universal" human rights were best protected through the broad-based norm of nondiscrimination. Most of the international instruments of the decades that followed reflected this view:

- The United Nations Charter affirms in its preamble "faith in fundamental human rights, in the dignity and worth of the human person, in the equal rights of men and women." It then states in Article 1(3) that one of its purposes is to promote and encourage "respect for human rights and for fundamental freedoms for all without distinction" on the basis of sex or any other grounds.

- Article 2 of the Universal Declaration of Human Rights broadly formulates the norm of nondiscrimination, entitling all to "the rights and freedoms set forth in this Declaration, without distinction of any kind," including distinctions based on sex.

- The general norm of non-discrimination is enshrined in the twin Covenants of 1966: the International Covenant on Civil and Political Rights (ICCPR) and the International Covenant on Economic, Social and Cultural Rights (IESCR). Each contains in Article 3, in almost identical terms, a special provision requiring states that sign the Covenant to ensure the equality of men and women in the enjoyment of the rights enumerated in the document. Both Covenants include a general non-discrimination article that covers gender. The ICCPR contains, in addition, Article 26 - a free-standing, non-discrimination provision.

The general norm barring sex-based discrimination is found in all major human rights treaties and is reinforced by a number of conventions and other international instruments that have particular importance for women. These include:

- The 1990 Convention on the Rights of the Child, which prohibits discrimination on the basis of gender in Article 2;

- The 1949 Convention for the Suppression of the Traffic in Persons and the Exploitation of the Prostitution of Others;

- The 1962 Convention on Consent to Marriage, the Minimum Age for Marriage and the Registration of Marriages;

- The ILO's Conventions No.s 100, 111 and 156, concerning equal remuneration for work of equal value, discrimination in respect of employment and occupation and workers with family responsibilities;

- The UNESCO Convention against Discrimination in Education, 1960. 
Finally, institutions dedicated to issues of central concern to women are dramatically under-resourced and ill-equipped compared with other bodies within the human rights establishment. Consequently, their implementation mechanisms and procedures have been, comparatively, ineffective and have less visibility and clout.

\section{Human Rights from a Gender Perspective}

The UN Charter and other instruments that guarantee equality, non-discrimination, or non-distinction on the basis of sex do not create rights for women that are specific to their day-to-day reality. Rather, they offer women the opportunity to exercise, on the same basis as men, rights that are universally recognized and inherent because of men's and women's common humanity.

These instruments are gender-neutral: they confer on women the right to be placed in the same situation as men in all those facets of life addressed by the particular treaty. They envisage the human condition as gender-free. But the human condition is not gender-free. There are some aspects of life that are common to women and men, and, clearly, women should be accorded equal opportunity in those areas. In general, however, women and men lead very different lives.

In the final analysis, guarantees of equality in the core human rights instruments are inadequate and, to some extent, irrelevant, because these rights have been defined in relation to the lives of men and to those few women who live their lives as publicly as men. An enumeration of human rights which reflected the realities of most women's lives would look very different indeed. It would focus, for example, on autonomy within the family, conditions suitable for healthy reproduction, sufficient economic resources to sustain oneself and one's family, and adequate food and shelter.

For most women a relevant rights regime would be one that not only guaranteed equality with men in those areas of life that are common to the sexes, but would also promote social justice in private and civil life. It would pursue the collective interests of humanity in a way that integrates the perspectives of women.

In addition, it would stress freedom from gender-based violence. Current human rights instruments reflect male experience in a world of men; they largely ignore the fact that around the world, most women live daily with violence or the threat of violence. For example, the right to be free from torture, as defined in international human rights law, fails to encompass violence in the family. Many legal systems fail to adequately address this issue. Some regard it as culturally acceptable, others say that it is inevitable. Moreover, the definition of torture does not include sexual assault, which many states still fail to acknowledge as a serious issue warranting legal and administrative action and provision of services. It excludes the growing incidence of seemingly random, but very often systematic, acts of violence directed at women in situations of economic, civil or political turmoil, or during international and civil warfare.

\section{Challenging the Principle of State Responsibility}

Unlike other human rights treaties, CEDAW specifically obliges states which ratify the Convention to take all appropriate measures to eliminate discrimination against women by any person, organization or enterprise.

This provision is a major achievement, because international human rights treaties are usually limited to the conduct of the state or its agencies, adhering to the international legal principle of state responsibility. This principle makes a state legally accountable only for those breaches of international obligations that are attributable or imputable directly to the state. In this legal context, only a state or its agents can commit a human rights violation.

Responsibility may sometimes be attached to the actions of those directly related to the state, such as the military. But generally speaking, non-state actors are not accountable under international human rights law. In this way, the notion of state responsibility means that the state is only accountable for its 


\section{CEDAW: A Landmark in Women's Human Rights}

The approval, in 1979, of the Convention on the Elimination of All Forms of Discrimination against Women (CEDAW), was a landmark in the history of women's human rights. CEDAW incorporated the norm against gender-based discrimination as well as all of the standards relating to women or having particular significance for women that had been set in past instruments.

CEDAW's preamble acknowledges that despite the UN's various efforts to promote human rights and the equality of women, "extensive discrimination against women continues to exist." It declares, moreover, that this discrimination violates "the principles of equality of rights and respect for human dignity, is an obstacle to the participation of women, on equal terms with men, in the political, social, economic and cultural life of their countries, hampers the growth of the prosperity of society and the family and makes more difficult the full development of the potentialities of the sexes and human, national and global development."

CEDAW moves beyond the guarantees of equality before the law and equal protection under the law found in earlier instruments. It sets out measures aimed at achieving substantive equality between men and women, regardless of marital status, in all fields of political, economic, social and cultural life. Unlike previous international instruments concerned with women's status, CEDAW allows for temporary measures of affirmative action. It binds states parties to seek to modify cultural patterns of behaviour and attitudes regarding the sexes, and attempts to impose standards of equality and non-discrimination in private as well as public life.

The normative framework created by CEDAW was reinforced recently by the United Nations Declaration Against Violence against Women. While not legally binding, this Declaration represents a moral commitment on the part of member states to introduce a number of immediate and progressive measures to address gender-based violence against women.

In addition, a number of mechanisms have been established to encourage the implementation of women's human rights. The most important of these are:

- The Commission on the Status of Women;

- The Committee on the Elimination of Discrimination against Women; and

- The Special Rapporteur on violence against women, its causes and consequences.

\section{Towards the Next Century: Major Challenges}

Despite these substantial legal and procedural achievements, the majority of the world's women and girls remain excluded from the prevailing vision of human rights. There are complex regional and country-specific reasons for this. One contributing factor is the fact that the impressive existing legal and procedural international human rights framework has not been applied with sufficient force or consistency to redress the disadvantages and injustices experienced by women on the basis of their gender. There have been three major obstacles to this:

First, those rights that have been targeted as universal human rights - and to which women have been assured equal access - while important, do not necessarily encompass all of women's experiences. Issues of immediate concern to most women have not been defined as issues of human rights. As a result, human rights institutions and bodies (except for those specifically dedicated to women) have not addressed women's most urgent concerns as issues of human rights; when they have done so, they have not proceeded in a comprehensive and serious manner.

Second, the current human rights framework is cast in terms of discrete rights and therefore cannot adequately address the pervasive, structural and systemic denial of rights that affects women and girls world-wide. 
direct actions, or those of its agents, that violate the rights of individuals (such as torture, wrongful imprisonment, or summary or arbitrary executions), and to discrimination by the state or its agents in the exercise of established rights.

Many women suffer gender-based violations of rights through direct actions of the state. For example, sexual violence is frequently used by state officials as a method of torture or by soldiers as an instrument of war. Female detainees are at greater risk of gender-based violence than their male counterparts. Studies indicate that female refugees are at high risk of sexual and physical violence during flight, on arrival in refugee camps, and when they are finally settled. While there should be little difficulty in establishing state responsibility for these violations, in practice, it is often difficult. Decision-makers have proven to be easily persuaded that sexual violations constitute individual, rather than state-linked, activity.

Most violations of women's rights occur in other, more private spheres of life and at the hands of private individuals. As a result, it is more difficult to make a case for state responsibility. Domestic violence, sexual abuse of women in the workplace and elsewhere, trafficking in women and denial of reproductive choice are all examples of the violations that women commonly experience. While these acts are not directly attributable to the state, states may and often do actively maintain a cultural, social or legal system that tolerates these violations or fails to take positive measures to prevent them. Discrimination within the family is not technically discrimination by the state or its agents; but here again, many states maintain a cultural context that legitimizes the subjugation of women in what should be the smallest democracy at the core of society.

\section{Affirming Social, Economic and Cultural Rights}

Another achievement of CEDAW is its insistence on the indivisibility of human rights - a principle that is often affirmed on paper but rarely extended to policy.

Human rights discourse affirms that all rights - not only civil and political, but also social, economic, and cultural - are indivisible and interdependent. It stresses that the promotion and enjoyment of certain fundamental freedoms cannot justify the denial of other human rights and fundamental freedoms. These concepts of "indivisibility and interdependence" were reiterated and confirmed at the World Conference on Human Rights, and are restated in both the Vienna Declaration and Programme of Action and the final document of the International Conference on Population and Development in Cairo in 1994.

Here again, there exists a wide gap between theory and practice. In practice, international human rights law tends to give priority to civil and political rights, devaluing social, economic, and cultural rights and thereby marginalizing some of women's most pressing concerns.

Clearly the universal realization of civil and political rights is crucial. But the priority given to these rights has shifted economic, social and cultural rights away from centre stage. Some of the most urgent concerns of women's day-to-day existence involve the denial of economic, social or cultural rights. These include the calamitous impact of structural adjustment policies on women's ability to sustain themselves and their families; or the devastating effect of environmental degradation on the quality of their daily lives. These issues have been effectively marginalized. At the same time, the human rights establishment has failed to take adequate account of the economic, social, and cultural subordination that inhibits many women from claiming even their basic civil and political rights.

\section{Strengthening CEDAW}

There is mounting evidence that the state obligation to guarantee rights to women calls for measures which are substantively different from those needed to guarantee the same rights to men. Policies that are strictly gender-neutral often fail to protect girls and women from the kinds of discrimination that threaten their autonomy, their security, even their very lives. Most international human rights 
mechanisms, including those under the aegis of the United Nations, are just beginning to come to terms with this fact. Many of these bodies continue to define rights in gender-neutral terms; they do not refer specifically to women, either explicitly or by means of a formula suggesting equality or nondiscrimination.

By elaborating the meaning and scope of discrimination against women, CEDAW has provided a vital tool to advocates of human rights for women. Together, the Convention and the General Recommendations of the CEDAW Committee have proven to be effective tools for those who are establishing an international human rights framework that is relevant to the majority of the world's women. And in countries around the world, these tools have been powerful instruments for those working to eliminate or reform discriminatory laws and practices.

At the same time, advocates recognize that CEDAW has yet to fully realize its promise for women. They point to the issue of reservations. Judging by the number of ratifications, accessions and signatures, CEDAW is second only to the Convention on the Rights of the Child as the most widely endorsed UN human rights treaty. At the same time, it is the treaty to which countries have entered the greatest number of substantive reservations.

Some of these reservations strike at the heart of the concepts of gender equity and non-discrimintion - the very foundation of CEDAW. They divest women of the Convention's guarantees of equality, and strip women of guarantees of equality and non-discrimination enumerated in other treaties and instruments. Other reservations maintain the general thrust of the treaty obligation, but preserve the power of states parties to continue discrimination in particular spheres by maintaining discriminatory laws, practices and patterns of behaviour. Most frequently, states' reservations exclude from the reach of their treaty obligations the family - the very sphere where rights for women are most crucial.

The CEDAW Committee has expressed alarm at both the number and the breadth of the reservations. The Vienna Declaration and Programme of Action encouraged the Committee to continue its review of reservations to the Convention and urged countries to withdraw those "that are contrary to the object and the purpose of the Convention or which are otherwise incompatible with international treaty law."

CEDAW contains no internal mechanism to reject reservations considered to be inconsistent with the object and purposes of its obligations. This absence represents a major challenge to advocates of women's human rights, who are determined to strengthen CEDAW in five areas:

- First, they want to strengthen CEDAW's implementation and monitoring procedures - in particular, its investigatory and enforcement powers. They believe that the CEDAW Committee should have a mandate to evaluate and reject reservations that are incompatible with the objectives of the Convention; to demand that ratifying countries submit reports; and to sanction states that fail to comply with the terms of the Convention.

- Second, they want to provide for the resolution of interstate or individual complaints related to non-compliance with CEDAW.

- Third, they seek wider recognition of the role of NGOs, who at present have no formal status or powers in relation to CEDAW. For example, they want the Committee to encourage NGOs to submit shadow reports on their countries' compliance with CEDAW, even in cases where the NGOs have no right to make formal representations to the Committee.

- Fourth, they urge greater attention be given to CEDAW by the lawyers and political scientists who are developing the jurisprudence of human rights and absorbing human rights standards into national law. 
- Finally, they seek a more appropriate level of funding for CEDAW and the CEDAW Committee. From the outset, the Committee has been plagued by resource constraints. The Committee's meeting schedule and time has been shorter than that of any other comparable body, and compared with other human rights treaty bodies, provision for its servicing has been extremely limited.

Steps have been taken to move towards these goals. The Vienna Declaration and Programme of Action has directed the UN Commission on the Status of Women and the CEDAW Committee, as a matter of urgency, to examine the possibility of preparing an optional protocol creating a complaints procedure under CEDAW. A draft protocol is likely to be considered by the Committee at its session in 1995.

To secure proper recognition and resourcing of the Commission on the Status of Women, CEDAW and the CEDAW Committee - and indeed, to make any headway in women's human rights in general women's NGOs must exert continuing pressure on the international human rights community to concretize the spirit of the Vienna document and to realize the commitments made by states in resolutions of the Human Rights Commission and the General Assembly.

A great deal has been accomplished in recent years, and CEDAW certainly represents a long stride toward the goal of gender equity. But as we approach a new century, advocates of women's human rights readily acknowledge that the greatest challenges lie ahead. 


\section{Gender-Based Violence}

Women, in both the North and the South, live daily with the risk of physical harm in ways that have no direct parallels for men. In virtually every nation, violence or the threat of violence, constricts the range of choices open to women and girls in almost every area of life, public and private - at home, in school, in the workplace and in most community spaces. It limits their choices directly by destroying their health, disrupting their lives, and narrowing the scope of their activity; and indirectly by eroding their self-confidence and self-esteem. In all of these ways, violence impedes women's full participation in society.

The wide range of discriminatory and criminal practices that constitute gender-based violence cause tremendous suffering for individual women and girls, and exact incalculable social costs as well. In fact, there are many fewer women living on earth today than we would expect, based on well-established ratios of women to men. Roughly 90 million women who should be alive today are "missing" due to the effects of gender discrimination.

Researchers have made strides in gauging the dimensions of gender-based violence, despite the obvious and severe problems of data collection. In virtually every country, crime statistics grossly under-report violence against women, particularly battery and sexual assault within the family setting.

Domestic violence affects women in the North and the South. Survey data compiled by the United Nations Statistical Office indicate that about one in four women in industrialized regions has been hit by an intimate partner. Data collection is beginning in many developing countries as well. One review of 90 peasant and small-scale societies found significant levels of violence against women in 74 of them; the remaining 16 were described as "essentially free or untroubled by family violence."

Statistics on rape from industrialized and developing countries suggest remarkably similar rates: between one in five and one in seven women will be the victim of rape during their lifetimes. Data compiled from eight countries (representing both industrialized and the developing nations) show that most of the time, perpetrators of sexual assault are known to the victim.

Women are especially vulnerable to sexual abuse in the context of war and state militarism and in a range of other political, social and cultural upheavals. In the history of international law, sexual abuse has been largely invisible, according to legal analysts. Forced impregnation, for example, has never been explicitly recognized or redressed as a war crime by any international convention or tribunal. Legal analysts are now making efforts to create a legal framework that addresses the full range of human rights abuses that women suffer in war.

Gender-based violence is often fatal. Statistics from places as diverse as Bangladesh, Brazil, Canada, Kenya, Papua New Guinea and Thailand demonstrate that more than half of all murders of women were committed by present or former partners. Suicide by women is often associated with other forms of violence against them. For example, the World Bank estimates that battered women are 12 times more likely than other women to attempt suicide.

Gender-based violence also encompasses life-threatening deprivation of resources. According to the World Health Organization, girls in many developing countries receive less nourishment and suffer from malnutrition at higher rates than boys. Girls also receive less health care. In many parts of the world, North and South, women suffer physical and psychological damage from practices rooted in culture and tradition, including female genital mutilation, which affects an estimated 85 to 114 million girls and

(over...) 
women. Other harmful practices rooted in culture and tradition include: servile or mercenary marriage; child marriage; the preference for sons, leading to selective abortion and female infanticide; and eating disorders, common in western industrialized societies and Japan where many girls and women undermine their health in order to conform to cultural standards of beauty.

There is growing recognition that violence against women constitutes abuse of their human rights a principle that is reflected in the International Convention on the Elimination of All Forms of Discrimination against Women. CEDAW provides a working forum for the process of eradicating gender-based violence and promoting gender equity in the international community and at every level of national life.

In its General Recommendation No. 19, the CEDAW Committee notes:

Traditional attitudes by which women are regarded as subordinate to men or as having stereotyped roles perpetuate widespread practices involving violence or coercion, such as family violence and abuse, forced marriage, dowry deaths, acid attacks, and female circumcision. Such prejudices and practices may justify gender-based violence as a form of protection or control of women. The effect of such violence on the physical and mental integrity of women is to deprive them of equal enjoyment, exercise, and knowledge of human rights and fundamental freedoms.

By situating violence against women within the discourse on human rights, CEDAW helps to create a normative framework in which governments and government leaders can be held responsible and accountable for combatting violence against women.

Working for CEDAW's universal ratification, supporting its funding and advocating for stronger enforcement mechanisms are critical steps in the struggle against gender-based violence. 


\section{Legal Status and Legal Reality}

Promoting gender equality is, in part, a legal process. Indeed, many governments and international bodies have begun the process of revising discriminatory laws and enacting new measures that affirm women's right to personal liberty and protect them from bias. There is growing recognition that equality before and under the law is a fundamental human right.

These aie positive developments, but formidable challenges remain. Women's low status everywhere has been encoded in law, and women continue to face injustice solely on the basis of their gender in virtually every country. Where legal reform has been won, reality generally lags far behind. Even where gender equality has been constitutionally mandated, legal remedies for discrimination are typically non-existent or exasperatingly slow to work. The resulting injustices have not only undermined women's personal liberty and security; they have also limited their economic capacity, impoverishing millions of women and their dependents.

Clearly, there is sharp variation among and within nations, based in part on political and cultural history. For example, former colonies of France (primarily in Africa) and of Spain (primarily in Latin America) that retained the Napoleonic Code when they became independent tend to restrict women's civil status more severely than countries steeped in the British legal tradition. Countries where personal status laws (governing marriage, divorce, inheritance, child custody, etc.) are governed by religious codes tend to discriminate against women more than those where uniform secular civil laws determine personal status.

Legal traditions and legal systems may discriminate against women in many ways. First, gender bias may be institutionalized through laws - both enacted laws and customary laws - that explicitly discriminate against women. Here are some examples:

- The constitution of Kenya explicitly states that the prohibition of discrimination against women does not apply to matters governed by personal or customary law, or matters regarding property.

- Employment statutes may legalize discrimination against women in terms of wages, promotions and benefits, including training opportunities. This is the case, for example, in Zambia.

- Land ownership laws, such as those in Kenya, Swaziland, Zimbabwe, and other countries, limit women's rights to own land.

- Inheritance laws may bar a woman from inheriting property owned by her father or husband. In Togo, for example, a widow may be deprived of all marital property (including household chattel) by her husband's family.

- Tax laws may discriminate against women. In Switzerland, married women may not fill out their own income tax forms; their husbands must do it for them.

Second, countries may enact laws that appear on paper to be gender-neutral but in fact discriminate agains women.

- Credit laws and practices may, as written, appear to be gender-neutral. They may, however, discriminate against women by requiring collateral in the form of land or other productive property to which most women have no access. This is the case in Ghana and Kenya.

- Constitutions may fail to bar discrimination against women in vital areas such as property, employment and access to education and health services.

Third, there may be inconsistencies in the substance of higher-level and lower-level laws that result in gender bias.

- In Zaire, the Constitution bars discrimination on the basis of sex, but the Family Code requires a wife to obtain her husband's signature for all legal acts to which she is a party.

(over...) 
Fourth, well established, deeply entrenched procedures or conventions (outside the legal framework) may attain the force of law, discriminating against women and in some cases abrogating established law.

- In Swaziland, the Age of Majority Act grants women and men adult legal status at age 21.

Nevertheless, government officials routinely require written permission from a male relative before issuing a passport to a woman.

- In Cameroon, laws now give women the right to land ownership, but burdensome administrative procedures make it extremely difficult, if not impossible, for most women to claim this right.

- In many countries, health care workers routinely require a husband's consent to perform medical procedures or prescribe contraceptives, even if the law does not require it.

Fifth, established law may be abrogated by traditional practices and religious custom.

- In some societies where Islamic law gives women property rights, these rights are often ignored in practice; while women may have title to the property, control of the property lies solely in the hands of men.

Sixth, laws barring discrimination against women may fail to incorporate enforcement measures.

- In Japan, the Equal Employment Opportunity Law affirms the principle of equality in hiring, training, and benefits, but includes no penalties for violation of the statute; compliance depends on the employer's good will or perception that a commitment to gender equity offers a competitive advantage.

Finally, economic and political factors also limit women's capacity to realize the rights guaranteed to them by law. A recent report by the International Women's Rights Action Watch, a group that monitors compliance with CEDAW, noted that: "In all countries women's relative poverty, lack of education or knowledge of their rights, and their socialization frequently prevent them from asserting themselves to claim their legal rights."

- In the U.S., where women have the legal right to abortion, millions of young and poor women have been cut off from abortion services by lack of government funding, decreases in providers, harassment and violence against clinic personnel and state legislative restrictions such as parental consent and enforced waiting periods.

- Guyana has progressive laws in relation to women, but women's total responsibility for the home and their burdensome workload prevent them from taking advantage of these laws.

The gender perspective needs to be positioned in the courtroom as well as in the constitution. Ensuring legal personhood means not only revising laws that are discriminatory, and enforcing laws that bar discrimination, but also launching programmes in gender education for judges and other court personnel. After all, the institutions that enact and enforce laws are not neutral; they have been constructed by societies dominated by men, and they reflect their interests and bias. The people who enact, interpret and enforce legal codes are not immune to the force of culture and tradition. Their actions and decisions tend to reflect the attitudes of their culture, including assumptions about the role of women and the nature of male-female relations. Studies of gender in the courts of Canada and the United States, for example, have found that the interpretation and the application of the law, which hinges on the attitudes of individual judges and court personnel, are often unfair to women.

CEDAW is rooted in the conviction that law-both international and national-is a powerful tool in the struggle for social and economic justice. In affirming that a single standard of gender equity must prevail beyond considerations of family, culture or nation, CEDAW provides a working agenda for moving toward gender equity. Promoting women's legal capacity in practice as well as in law means infusing a gender perspective into every aspect of daily life.

CEDAW obliges governments to ensure women's right to personal liberty and freedom from discrimination. But it does not stop there. CEDAW specifies that legal guarantees must not only be enshrined in law, but also enforced in practice. "States parties shall accord to women equality with men before the law [and] a legal capacity identical to that of men and the same opportunities to exercise that capacity" (Article 15, $1 \& 2$ ). CEDAW's blueprint for national action provides an international standard for promoting gender equality and an important framework for guaranteeing individual rights against the competing claims of culture and family. 
. Economic Rights

Women all over the world perform multiple roles in productive labour, paid and unpaid, that are not reflected in official measures of economic activity. Their access to equal pay for comparable work, family benefits, financial credit and the right to own and inherit property are either non-existent or are sharply limited by law and the traditional or religious practices that continue to undergird economic life. All of these inequities are even more detrimental in light of the fact that, to a greater extent than ever before, women bear disproportionate responsibility for supporting and sustaining the world's children.

Examples of this include the following:

- In the poorest countries, women support entire segments of the population by paid and unpaid labour that demands a work-week consisting of 70 hours or more.

- Traditional measures of economic output dramatically undervalue women's contributions. Case in point: after the International Labour Organization set a new international standard for the definition of the production of economic goods, India's estimate that only 13 per cent of Indian women were "economically active" was boosted to 88 per cent.

- In many nations around the world, women are denied the earning power that comes with formal education. Two thirds of the world's 960 million illiterates are female; women account for 70 percent of China's 180 million illiterates.

- Land title acts and traditional practice often exclude women, particularly married women, from taking title to land, even in progressive redistribution schemes. Statutory systems, notably in India and parts of Africa, follow religion and custom in denying women property rights, either by forbidding female inheritance or by placing administrative power solely with men.

- In many countries, women are overrepresented in the contingent workforce - those who work without benefits or protection. In the U.S., thousands of African-American and Latina women, including many immigrants from the Caribbean and Latin America, labour as home health care workers with low pay and no benefits. Asian and Latina immigrants staff urban garment sweatshops by the thousands, working long hours with no benefits or protection and beneathsubsistence pay; their children are sometimes used to fulfill work quotas.

- Legal and cultural obstacles to owning and managing property are a major cause of women's poverty. A recent United States Agency for International Development (AID) report found that legal status limited women's participation in approximately half of AID's development projects.

Virtually every political system - whether state socialist, authoritarian or democratic - has neglected the situation of women in examining the class or racial inequities of national economic life. The traditional sexual division of labour, which treats domestic caretaking and home maintenance as expected, voluntary contributions by women prevails at every income level and perpetuates inequity. Governments need to create legislative measures to enable and spur women's economic participation, including the right to equity in property ownership and administration, inheritance, access to credit, and all other matters of property, labour, and finance.

The International Convention on the Elimination of All Forms of Discrimination against Women promotes gender equality as the engine of law and policy reform, requiring ratifying states to monitor and report on progress in removing whatever legal and cultural barriers impede women from "a legal

(over...) 
capacity identical to that of men and the same opportunities to exercise that capacity." This includes, "equal rights to conclude contracts and to administer property" (Article 15). Governments are specifically charged with guaranteeing the same rights for both spouses in respect of the ownership, acquisition, management, administration, enjoyment and disposition of property" (Article 16). CEDAW, likewise, óbligates governments to ensure women obtain access to family benefits, bank loans, mortgages, and other forms of credit on a basis identical to that of men.

Globally, women are the sustainers of family life, and in developing countries they typically produce 60 to 80 per cent of the food. If economic development efforts are to succeed, they must acknowledge the gender-based organization of law and culture, and build, into every strategy and every policy, measures designed to move women from marginalization to empowerment. Until its economic life is equitable, inclusive and human-centred, no nation can thrive.

Today, many of the concerns once dismissed as "women's issues" are at the centre of development policy. There is growing consensus that without the advancement of women, development will be stalled at the crossroads of crisis and unworkable, outdated strategies for change. In working toward the universal ratification of CEDAW, decision-makers recognize the unique opportunity it offers to hoist economic equity high on the world's development agenda, not because it enhances human progress, but because none is now possible without it. 


\section{Girls' Rights}

Societies world-wide continue to place girls in peril that is so routine it is virtually invisible. In countries of every economic and social profile, gender inequity is deeply ingrained in girls' lives from birth - or even earlier. A wide range of violent or discriminatory practices compromise girls' health and shrink their chances for productive development. This is not random violence; the risk factor is being female.

- In some parts of the world, including China, India and the Republic of Korea, access to amniocentesis and ultrasound techniques to determine the sex of the feotus are sufficiently widespread to allow selective abortion and the consequent skewing of male-female sex ratios. This practice is rooted in the social and cultural stigma attached to having girl children and the considerable costs of marrying off a daughter. Some countries, including China, are beginning to enact legislation to limit this practice.

- Infanticide is believed to account, in part, for distorted male-female sex ratios in many developing countries. One study in a remote region of Southern India found that 58 per cent of deaths among female infants were due to infanticide, usually within seven days of birth.

- Female genital mutilation - the ritual cutting and removal of all or part of the clitoris and other external genitalia - affects an estimated two million girls and women each year, mainly in Africa. Most commonly, girls undergo this ritual between the ages of four and eight.

- Nurture discrimination is the greatest cause of sickness and death among females between birth and age 5. According to the World Health Organization, girls in many developing countries receive less nourishment than boys. They are breast-fed for shorter periods of time, receive fewer calories, and suffer from malnutrition (leading to death or to mental or physical disability) at higher rates than boys. In rural Bangladesh, malnutrition has been found to be almost three times more common among girls than boys.

- Girls also have less access to health care. Studies show boys outnumbering girls at diarrhoeal treatment centers, although both sexes suffer from diarrhoea with equal frequency. For all of these reasons, the mortality rate among girls is one to four times higher than among boys in 43 of the 45 countries for which data are available.

- Early marriage (typically arranged) compromises the health and autonomy of millions of young girls. In many parts of the developing world, significant numbers of brides are younger than 15. (Many countries have formally adopted a legal minimum age for marriage above 15 , but only in cases where parents withhold consent.) The minimum marriageable age for women in many countries - including Chile, Ecuador, Panama, Paraguay, Sri Lanka, and Venezuela - is 12. In many other countries, legislation has set the minimum age at 16 or above, but traditional practices often persist.

- Early marriage leads to early maternity, further undermining girls' health. The World Health Organization recently reported that in parts of Asia, maternal mortality is five times higher among girls aged 10 to 14 than among women aged 20 to 24 . Because a young woman's pelvis may be too narrow for childbirth, obstructed labor is among the serious risks of early pregnancy; this is further complicated for women who have undergone female genital mutilation, which doubles the risk of maternal death. Early maternity also deprives girls of education, foreclosing their hopes for future employment.

- Girls are frequent targets of sexual abuse, in part because they lack the status and the education to advocate for themselves, especially in negotiating abstinence and protected sex. There have been few population-based studies on the sexual abuse of children and adolescents; however, those that exist

(over...) 
suggest that it is widespread. There is also substantial indirect evidence of the sexual abuse of children, including alarming numbers of very young girls being treated for sexually transmitted diseases (STDs). For example, a 1988 study conducted in Zaria, Nigeria, found that 16 per cent of female patients treated for STDs were under age 5.

- Girls are particularly vulnerable to rape, including gang rape, in areas where HIV infection is widespread. This reflects the conviction among many adult men that they will have less risk of HIV exposure if they engage in sexcual intercourse with girls and very young women. Increasing numbers of girls are contracting HIV and transmitting the virus to their children. World Health Organization's prediction of 10 million "AIDS orphans" by the year 2000 has shocked the international community.

- For the same reason, the demand for ever-younger child prostitutes is growing. According to the 1994 Human Development Report, conservative estimates put the combined number of child prostitutes in the Philippines, Sri Lanka and Thailand at half a million. Many child prostitutes become entrapped in prostitution while escaping abuse at home. A study conducted in Bolivia found that 79 per cent of girls said they became prostitutes after running away from homes where they were victims of incest and rape.

These practices have a devastating impact on girls' health, and place them at great risk throughout childhood. Moreover, those who do survive to adulthood can look forward to fewer educational and employment opportunities than their brothers. Families invest in sons in many parts of the world because they look to them as potential earners as well as sources of future support; daughters, often considered economic liabilities, nevertheless provide household and workplace labour so valuable that many families cannot spare them for the education that would so drastically improve their economic and social status.

Child labour is often veiled in industrial countries where, as elsewhere, it is subsumed into basic culture. For example, girls are being enlisted as almost full-time caretakers for younger siblings while their mothers work outside the home to support the family or attend classes in an attempt to improve their earning power. In Bangladesh, poverty and custom have created a class of child domestics, most of them girls, who are sent to work in urban households by their parents at age 6 or 7 , often living in a corner of the kitchen, eating scraps. UNICEF estimates that 400,000 children, most of them girls, labour in domestic work in New Delhi alone.

The United Nations Convention on the Rights of the Child and the International Convention on the Elimination of All Forms of Discrimination against Women both affirm social and economic rights as well as civil and political rights as human rights; both assert that the future life of any nation depends on promoting and protecting its children. CEDAW recognizes that no society can thrive in the absence of gender equity, and acknowledges the need for temporary special measures to achieve it.

Because discrimination against female children is so pervasive and so destructive to the social order, strengthening girls' rights offers a critical opportunity to enhance not only individual lives, but also the lives of nations. Girls' rights are inseparable from women's rights. Raising the needs of girls high on the international human rights agenda represents an important step toward carrying out one of CEDAW's most powerful and urgent mandates: "To modify the social and cultural patterns of conduct of men and women, with a view to achieving the elimination of prejudices and customary and all other practices which are based on the idea of the inferiority or the superiority of either of the sexes or on stereotyped roles for men and women" (CEDAW, Article 5a). CEDAW charges ratifying states with nothing less than reshaping culture. The challenge is immense, and resources are sparse. Meeting this challenge requires advocacy from all women and men who grasp the Convention's potential benefits - for today's girls and tomorrow's women, and for the communities they will empower and lead. 


\section{Women's Rights and Children's Rights}

Historically, the rights and status of women and children have depended solely on the laws and customs of the countries in which they lived. There has been no internationally recognized legal basis for establishing or protecting their rights. Today, that is no longer the case. Over the last two decades, the world has witnessed the adoption by the international community of two landmark treaties: the International Convention on the Elimination of All Forms of Discrimination against Women (CEDAW) and the Convention on the Rights of the Child (CRC).

CEDAW was adopted by the UN General Assembly in 1979 and entered into force in 1981. The CRC was adopted in 1989 and entered into force in 1990. To date, CEDAW has been ratified by 139 countries, and CRC by 168 countries. Judging by the number of ratifications, accessions, and signatures, these two treaties have proven to be the most widely endorsed human rights treaties in the history of the United Nations.

Both treaties derive from and are based upon the principles of human rights articulated in the Universal Declaration of Human Rights and the International Covenant on Human Rights. These principles were affirmed at the World Conference on Human Rights in June 1993. The Vienna Declaration and Programme of Action, which emerged from the Conference, affirmed that, "The human rights of women and the girl child are an inalienable, integral and indivisible part of human rights".

\section{Breaking New Ground}

Some have asked, if we already had a Universal Declaration of Human Rights, why did we need special treaties to protect women and children? The answer lies in history. Traditionally, most societies have denied women and children an independent legal and social status. Steeped in traditional patriarchal values, these societies placed women and children under the protective control of male authority within the family. Under the English common law and civil law systems derived from Roman law or the Napoleonic Civil Code, married women and children were classified with insane persons as individuals lacking the maturity and the intellectual capacity to exercise legal rights. Indeed, the Napoleonic Civil Code stated that "those persons without rights at law are minors, married women, criminals and the mentally deficient".

To address this fundamental inequity, it is not enough to affirm the rights of women and children as members of the human race. CEDAW and the CRC break new ground in international law by addressing directly the relationships among women, children, the family and the state. Both treaties reach beyond legal aims; they advance a vision of human society in which attitudes toward women and children are based on equity and fairness.

\section{Two Treaties - One Vision}

Together, the two treaties establish and protect the rights of women and girls. The substantive articles of both conventions reflect a single vision, based on international human rights law, rooted in the conviction that girls' rights and women's rights are inseparable, and recognizing the obvious - that the rights of girls today are the rights of tomorrow's women.

The Committee on the Rights of the Child has emphasized the compatibility of the two Conventions:

"The Convention on the Rights of the Child and the Convention on the Elimination of All Forms of Discrimination against Women have a complementary and mutually reinforcing nature and they should be an essential framework for a forward-looking strategy to promote and protect the fundamental rights of girls and women and decisively eradicate inequality and discrimination."

(January 1995)

(over...) 


\section{Shared Principles}

The two Conventions share these key principles:

\section{- They are anchored in a common view of human rights.}

Both CEDAW and the CRC seek to develop women's rights and child rights within the framework of the Universal Declaration of Human Rights and the International Covenant on Human Rights. Both affirm that human rights are indivisible and interdependent, and recognize that international cooperation is vital 'in securing these rights. Finally, both Covenants are guided by a broad concept of human rights that stretches beyond civil and political rights to the core issues of economic survival, health, education, and the environment that affect the quality of daily life for most women and children.

\section{- They focus on the particular needs of girls - the most vulnerable members of any society.}

Both Conventions require states parties to protect girls from any form of gender-based discrimination. In addition, both Conventions require states to play an active role - through both the public and private sectors - in protecting and caring for children of both sexes.

\section{- They recognize the important role of the family within society.}

Both Conventions refer to the vital importance of the family as a unit of society, without ignoring the realities of oppression and discrimination within family relationships. Both seek to strengthen supportive, caring, meaningful relationships within the family. They envision a family in which men and women enjoy equal rights and responsibilities, and girls enjoy the rights to equal opportunities with their male siblings. They call upon states to develop a range of social services and employment policies to strengthen families, such as child benefit schemes, child care services, and maternity and parental leave.

\section{- They attach particular importance to health and nutrition.}

Both Conventions affirm the right of girls to the highest attainable standard of health and nutrition. They recognize that supportive policies to improve the health and nutritional status of women and children are intrinsic to the welfare of the whole family.

\section{- They stress the right to a basic education.}

Both Conventions recognize the significance of female literacy in achieving child survival, growth and development. They stress gender equality in the realm of education, guaranteeing education rights, and equal opportunity to an education.

\section{- They call for the eradication of gender-based abuse and neglect.}

The two Conventions affirm the right to protection from battery and sexual abuse, including sexual trafficking. They affirm the right to protection from traditional practices that create health risks, including female genital mutilation and child marriage.

\section{- They seek to empower women and children through participatory rights.}

Because women and children are so vulnerable to discrimination and abuse, threatening their health, well-being, and even their survival, both Conventions stress protective measures. At the same time, both seek to empower women and girls through participatory rights, including the right to express one's opinion, to obtain information, to freedom of thought and association.

\section{A Formidable Code of Rights}

Adopted a decade after CEDAW, the CRC reflects a heightened awareness of the vital importance of building effective implementation and monitoring mechanisms into the Convention. For example, in order to conform with the spirit and principles of the CRC, states which ratify this Convention are bound to reform existing legislation and to enact new legislation. The CRC aiso introduces the concept of networking for implementation. States are required to make information about the treaty available through advocacy and public education, and to cooperate with the international community to ensure that certain provisions are met. In these ways the CRC can serve as a model for those who are seeking to strengthen the implementation and monitoring provisions of CEDAW.

CEDAW and the CRC together constitute a formidable code of rights for all children and women - a legal landmark along the road to a more humane and just world. 


\section{Women, Culture, and 'Traditional Practices'}

In both industrialized and developing countries, women and girls suffer the effects of harmful and sometimes life-threatening traditional practices, rooted in long-held cultural assumptions and/or religious beliefs.

The International Convention on the Elimination of All Forms of Discrimination against Women proceeds from the assumption that all practices that harm women, no matter how deeply they are imbedded in culture, must be eradicated. CEDAW calls upon governments to work toward transforming not only law, but also culture, in order to achieve gender equity. CEDAW provides a framework for change, supplying guidelines for ending those traditional practices that continue to harm and stereotype women under the guise of social conformism, economic necessity or cultural survival.

These practices include but are not limited to:

Female Genital Mutilation (FGM): Recent estimates indicate that from 85 to 114 million girls and women have undergone genital mutilation - the ritual removal of all or part of the clitoris and other external genitalia. Most of these cases have occurred in eastern and western Africa. In a number of countries, such as Djibouti, Mali, Sierra Leone, Somalia and large areas of Ethiopia and the Sudan, nearly all women are affected. Female genital mutilation can lead to death or infertility; during childbirth, it doubles the risk of maternal death. Practitioners claim that to question the ritual is to insult community elders, who sanction and often administer it, and to deny young women the sense of identity and initiation they need to join their culture as adults. In some areas, traditional practitioners are being replaced by medical personnel, who reduce the procedure's risk and thus offer the potential for further legitimacy.

Female Infanticide, Selective Abortion: In parts of China, India, and the Republic of Korea, despite sporadic legislation to prevent it, foeticide is routinely performed using amniocentesis and ultrasound procedures to preselect boys and abort female fetuses. One study showed that of 8,000 abortions performed at a particular Bombay clinic in 1984, 7,999 were of female fetuses. In parts of India, large numbers of female deaths, usually within seven days of birth, are attributed to infanticide based on son preference and the low value, even dread, associated with the birth of daughters.

Son Preference: Scarcity and tradition continue to encourage the preferential treatment of boys, who are regarded as potential earners and family supports and thus receive preferential nourishment and the high regard of their families. Meanwhile girls are neglected, malnourished and often forced into early marriage.

Dowry. While India has legally abolished the institution of dowry, the practice and its cultural force persist. There are increasing reports of husbands and mothers-in-law clandestinely murdering or injuring brides whose families fail to satisfy their financial demands.

Eating disorders: In western industrialized societies and Japan, the desire to conform to cultural standards of physical beauty causes many young girls and women to compromise their health. Studies suggest that roughly one of every 100 to 200 young women in these societies suffers from anorexia, a psychological disorder characterized by self-starvation, sometimes leading to death. Bulimia, a related disorder, is characterized by binge eating accompanied by purging.

In 1990, the Committee established by CEDAW specifically recommended that states parties act effectively to eliminate female genital mutilation "and other traditional practices harmful to the health

(over...) 
of women," charging the Convention's ratifying states to report on the measures taken to eliminate them. The CEDAW recommendation observes that "there are continuing cultural, traditional and economic pressures which help to perpetuate harmful practices," thus calling for state accountability for behaviour that is socially tolerated whether or not it is prohibited by law (CEDAW, General Recommendation No. 14., 1990).

The recommendation affirms CEDAW's Article 5, which calls on governments to eliminate "prejudices and customary and all other practices which are based on the idea of the inferiority or the superiority of either of the sexes or on stereotyped roles for men or women." CEDAW acknowledges that criminalizing such practices is not enough; eradicating them requires a broad-based recognition that societies can relinquish or alter long-held traditions without sacrificing their identity or stability.

Advocates of gender equity must recognize and challenge the social acceptance and perpetuation of harmful traditional practices in all cultures. Historically, religion and culture have proven extraordinarily adaptive; most belief systems have been revised over time to accommodate new understandings and new values that emerge in human society. As an African observer recently wrote, "Traditions are highly sacrosanct and untouchable where women are concerned. Still, I have seen traditions change during my lifetime. The change was so easy and smooth when the men took the initiative. Change, however, requires a lot of pain and hard work when it is initiated by women."

Numerous cultures offer examples of traditions - including customs harmful to women - that have changed or died out. For generations, women (and some men) in Sudan endured mutilation to acquire face marks, a traditional sign of beauty as well as an indicator of tribal affiliation. In recent years, this tradition has rapidly disappeared. The binding of women's feet in China is another example of a nearly universal custom that is no longer practiced.

Harmful traditional practices, including violence against women, often masquerade as bearing walls of culture; in reality, they are the ruins of an unsustainable past. By moving toward universal ratification of CEDAW and strengthening its enforcement mechanisms, advocates of women's human rights can support women as planners of the programmes and behaviours that will replace harmful customs with new practices that respond to current needs. 


\section{Reproductive Rights and Sexual Rights}

International human rights law recognizes that the enjoyment of the highest standard of health - including reproductive health - is one of the fundamental rights of every human being. Reproductive health does not simply mean the absence of disorders and disease, it implies that people have the ability to:

- Practice and enjoy sexual relationships and to be safe in having sex

- Reproduce

- Enjoy a safe pregnancy and childbirth

- Regulate fertility without sacrificing one's own health

- Carry pregnancy to a successful outcome through infant, child, and maternal survival, coupled with growth and healthy development.

Today, millions of women live in conditions where reproductive health is beyond their reach. In many parts of the world, their reproductive and sexual rights are severely curtailed by custom and law, as well as inadequate reproductive health services and information. The World Health Organization has established these facts about women's reproductive health:

- Around the world, an estimated 3 million couples do not have access to family planning services.

- Of the 910,000 conceptions that take place in the world every day, about 50 per cent are unplanned and about 25 per cent are unwanted.

- About 150,000 such pregnancies are terminated every day by induced abortion, one-third of which are performed under unsafe conditions.

- About 500 women die each day as a result of unsafe abortions.

- An estimated 500,000 women die each year - 1,370 each day - from avoidable causes related to uncontrolled fertility, complications of pregnancy and childbirth.

Many societies, according low status to women, accept a high incidence of maternal death as natural and inevitable. Two key points must be made:

First, maternal death is largely avoidable. In developing countries, where overall maternal mortality rates are 15 times higher than in industrialized countries, the major causes of maternal mortality are sepsis, hypertensive disorders, severe anaemia, and hemorrhage - all conditions that are widely prevented or successfully treated in industrialized countries.

Second, maternal death is the culmination of lifelong discrimination faced by girls and women in many parts of the world. In general, they receive less nutrition, less health care and less education than boys and men; girls and women also have less access to the information they need to make informed choices in their lives.

The right to set the terms for one's own sexual activity, including the right to refuse sex, is critical to sexual and reproductive health. Even when a woman has access to reliable information and health services, these rights exist in name only if her low household status prevents her from protecting herself - for example, by negotiating abstinence or condom use with her partner. Adolescent girls, vulnerable to pressure to engage in sexual activity, face especially high risks, including high maternal mortality and the possibility of contracting HIV/AIDS.

These issues are critical in the North as well as the South. Adolescent pregnancy is a growing problem in the United States, for example, where one in six babies is now born to a school-age mother. The U.S. birth rate for

(over...) 
white adolescents is higher than for teenagers in any other industrialized country; the figure for African-American teenagers is three times higher. Many young adolescents are impregnated by adult males, not by teenagers. Moreover, surveys indicate that significant numbers of girls experience their first intercourse involuntarily as victims of rape and/or incest.

The increasing risk of HIV makes it more urgent than ever for women to control their own sexual activity. Throughout the world, but particularly in sub-Saharan Africa, the ratio of female to male AIDS cases is rising. Recent studies of pregnant urban women have found rates of HIV infection ranging from five per cent in Burkina Faso to 28 per cent in Uganda, and rates as high as 80 percent among female prostitutes in Kenya.

Girls and young women are at particular risk, because men tend to assume that they are less likely to be infected with HIV; they may therefore be pressured or forced into sexual activity with multiple partners, and by older men. Girls and adolescents who are orphaned or otherwise unprotected due to the HIV death of parents, or due to civil strife, are particularly vulnerable to sexual abuse and to HIV infection.

Women have often been targets of international and national population policies aimed at controlling their fertility. In 1994, the International Conference on Population and Development, held in Cairo, recognized that the key to maintaining sustainable population growth lies in empowering women and enhancing their status, not in coercive population policies. The Conference proceedings reflected a growing recognition that inequalities between women and men, both in the private and public spheres, can have a major impact on population issues, and more generally on the success of sustainable development. The ability to plan the number and spacing of children affects not orily women's reproductive roles, but also their productive roles - their ability to participate in the economic, cultural, social and political life of their communities.

CEDAW affirms women's reproductive rights as human rights and requires ratifying states to eliminate discrimina- tion against women in health care and family planning. Specifically, CEDAW obliges governments to develop family codes that guarantee women's rights "to decide freely and responsibly on the number and spacing of their children and to have access to the information, education, and means to enable them to exercise these rights" (Introduction and Article 16e). This recognition - that the ability to secure human rights requires both the power and the resources to exercise them - is the Convention's great strength.

CEDAW requires governments to regulate not only public life but the private behavior that - protected in the past by assertions of culture and tradition - keeps women from exercising the human rights the treaty proclaims for them. Exerting an ongoing wedge against the status quo, the Convention's preamble notes "that a change in the traditional role of men as well as the role of women in society and in the family is needed to achieve full equality of men and women."

As of January, 1995, 139 states have ratified CEDAW, and some have done so with formal "reservations" about marriage and family law - precisely those institutions that most deny women reproductive and sexual rights. Abortion remains the most sensitive and divisive issue in the realm of women's reproductive rights. Research shows that regardless of abortion's legal status, a woman who wants an abortion will usually have one. Proponents of criminalizing abortion have not been deterred by estimates that about 70,000 women die each year as a result of undergoing unsafe abortions. A study in Nigeria found that "abortion complications accounted for 72 per cent of all deaths of young women under 19." Although CEDAW makes no specific mention of abortion, the Committee that monitors its implementation routinely asks ratifying states about the current status of abortion rights and reports on the situation in each country.

Despite the large number of reservations to the Convention, governments' conformity in the treaty's other areas is the beginning of a process, raising the hope that the entire international community will come to recognize that sustainable development cannot be accomplished until discrimination against women is eliminated in the private as well as the public sphere. 


\section{Women and Amed Conflict}

War devastates all of civil society - men and women. But armed conflict, political instability, civil unrest, occupation and other situations of upheaval inflict particular suffering upon women in the form of systematic murder, torture and sexual abuse, including rape. Adolescent and young girls are particularly vulnerable in these circumstances.

Cross-cultural studies are beginning to document the extent and severity of violence against women in their homes and communities. Recent research supports the view, articulated in the United Nations' document Women: Challenges to the Year 2000, that violence on the personal and international levels are in fact inextricably linked.

The literature points to these trends:

- Women and children are, more likely than ever before, to be killed or wounded in wartime. While only 5 per cent of casualties in World War I were civilians, in conflicts currently underway the figure is almost 80 per cent. A recent UN report confirms that, "Armed conflicts in Central America, the Middle East and Africa are leaving behind an increasing number of civilian casualties, a growing proportion of which are women."

- Women are increasingly the specific targets of aggression during wartime - sometimes due to their perceived power and resistance to the status quo; sometimes due to their perceived vulnerability. Amnesty International has shown that aggressors, whether government or subversive forces, harm women directly through disappearances, arbitrary arrests and imprisonment, as well as maltreatment, torture, and summary execution.

- Systematic mass rape (including gang rape), and forced impregnation have been documented as weapons of war and/or ethnic cleansing in many parts of the world, including Bangladesh, Cambodia, Cyprus, Haiti, Liberia, Peru, Somalia and Uganda. A European Community fact-finding team estimated that more than 20,000 Muslim women have been raped in Bosnia since fighting broke out there in April 1992. Observers note that all sides in that conflict have used rape as an instrument of war.

- There is growing evidence that war and civil unrest not only endanger women in the public sphere, they also intensify violence against women in the home. As one political analyst has noted, men who are unable to protect "their" women from violation may compensate by exercising violent control over their wives. A 1988 report of the UN High Commissioner on Refugees observes that "refugee women frequently suffer family violence due to pent-up frustrations and fragmentation of community life."

Women are also more likely to become the victims of trafficking and involuntary prostitution in times of war and upheaval, often with the complicity of government and military authorities. Japan's wartime abduction, imprisonment, and enforced prostitution of thousands of women to provide "comfort" to the Japanese army has been extensively documented. U.S. veterans of the war in Viet Nam and the literature of the period report widespread prostitution serving military personnel, both in Viet Nam and in other countries, such as Thailand, designated for the "rest and recreation" of troops. More recently, the Philippines and the Republic of Korea have been centres of military-related prostitution.

(over...) 
Violence against women often continues once hostilities end or women flee them: about three-quarters of the world's 20 million refugees are women and their dependents. These refugees are at particular risk of death: in refugee camps in Myanmar and Bangladesh, for example, women and children die at three times the rate of men.

Female refugees are vulnerable to violent assault and rape during flight and at border crossings, as well as in reception centres, refugee camps and settlements. Women and children account for more than 80 per cent of those living in refugee camps, but few refugee policies are designed specifically to meet their needs. In camps where men control and allocate rations, women and children are particularly vulnerable to sexual abuse. Displaced women (who have fled their homes but remain within the borders of their own countries) are also vulnerable to violence and abuse.

While statistics suggest the frequency of violent assaults against women in situations of upheaval, it is impossible to fully document the continuing terror and dread that invade daily life for women struggling not only to survive under these conditions, but also to protect children and elders.

A recent study points out that sexual assault against women civilians during armed conflict may be part of a strategy to suppress or punish the civilian population, or it may result from commanders' failure to discipline their troops. In either case, the report concludes, sexual assault is never a 'private' matter, and soldiers who rape may be prosecuted and punished as war criminals.

As in so many other spheres of international law, the legal basis for revising these conditions has been established but has gone largely unenforced. International human rights standards and humanitarian law, including the Geneva Conventions, explicitly prohibit violence against non-combatants and call for the protection of women against attacks on their honour, in particular against rape, enforced prostitution or any form of indecent assault. Rape was specifically enumerated in the Nuremberg trials as a crime against humanity. Governments have been slow to respond to violations of these international norms, however, and wars - both international and civil - continue to produce atrocities perpetrated against women and girls.

CEDAW provides a vital framework for achieving the gender perspective that is so crucial, and so often abandoned, during periods of stress. CEDAW's General Recommendation No. 19, articulated in 1992, affirms that "gender-based violence is a form of discrimination that seriously inhibits women's ability to enjoy rights and freedoms on a basis of equality with men," noting specifically "the right to equal protection according to humanitarian norms in time of international or internal armed conflict." CEDAW's Monitoring Committee has called upon ratifying governments to take preventive and legal measures against such violence, as well as to report to the Committee on all forms of gender-based violence, providing data on its incidence and effects, and the "legal, preventive and protective measures they have taken to overcome gender-based violence."

In the past, women have been called upon to develop the special skills needed to rebuild societies after crises, to restore shattered economies, and to create new social and educational networks. These skills have empowered women to support whole segments of their national populations; they need to be nourished at every level so that women can be shapers of the policies and programmes of the future. This cannot happen until governments and communities resolve that systematic violence against women in times of war and upheaval is wholly intolerable. 


\title{
The Convention at Work
}

\author{
The International Convention on the Elimination of All Forms of Discrimination against Women \\ (CEDAW) is, in essence, the international bill of rights for women. Acknowledging that the mere fact \\ of women's humanity has been insufficient to guarantee women protection of their rights by the existing \\ human rights standards and machinery, it brings together, in a single comprehensive international \\ human rights treaty, the provisions of existing United Nations instruments concerning discrimination \\ on the basis of sex and extends them further, creating a real tool for the elimination of discrimination \\ against women.
}

The Convention requires states to eliminate discrimination against women in the enjoyment of all civil, political, economic and cultural rights. It also establishes programmatic measures for states to pursue in achieving equality between women and men. States are obliged not only to work for equality in public life - for example, in the realm of legal status and political participation - but also in private life and, in particular, the family. In pursuing CEDAW's goals, states are entitled to introduce measures of affirmative action until equality between women and men is reached.

The Convention was adopted by the General Assembly in December 1979. Ratification was rapid, and the treaty came into force on September 3,1981. Currently, 139 countries - more than two-thirds of the members of the United Nations - are party to the Convention and an additional 44 countries have acceded to the treaty, binding themselves to do nothing in contravention of its terms.

\section{Committee on the Elimination of Discrimination against Women}

CEDAW authorized the formation of a Committee on the Elimination of Discrimination against Women to oversee implementation and monitoring of the Convention. The CEDAW Committee is comprised of experts in the field of women's rights from 23 countries. These 23 experts are elected by secret ballot from a list of individuals nominated by the countries that are party to the Convention. In this election, consideration is given to equitable geographical distribution, as well as to representation of different civilizations and legal systems. The 23 Committee members serve in their personal capacity, not as delegates or representatives of their countries of origin.

The Committee differs from other United Nations treaty bodies in two respects. First, since its initial session in 1982, all but one of its members have been women. Second, whereas most UN human rights treaty bodies are predominantly made up of lawyers and judges, the CEDAW Committee draws its members from a wide variety of disciplines; it has included economists, diplomats and sociologists. Both of these factors have contributed to the Committee's diverse and creative methods for implementing its mandate.

\section{Reporting on Compliance}

Every ratifying or acceding nation is obliged to report to the Committee on its efforts to meet CEDAW's goals within one year of signing the Convention, and then to follow up with progress reports every four years.

The Committee has adopted guidelines to help states prepare these reports. According to these guidelines, the initial report is intended to be a detailed and comprehensive description of the position of women in that country at the time of submission. It is meant to provide a benchmark against which subsequent progress can be measured. Second and subsequent national reports are intended to update the previous report, detailing significant developments that have occurred over the last four years, noting key trends, and identifying obstacles to the full achievement of the Convention. 
Initial reports are considered by the Committee in the presence of a representative of the reporting country, who may make a supplementary presentation. Individual members are free to ask for clarification or elaboration of any issue related to the report, the presentation, or to CEDAW's goals. Typically, the country representative returns a day or so later to respond to those questions; answers or supporting material are often presented in writing.

Since 1990, second and subsequent reports have been reviewed by a pre-session working group of five Committee members. The working group draws up questions to guide the full Committee's examination of the report. These questions are submitted to the country's representative in advance. The representative then meets with the Committee to respond to these questions and any others that members may wish to ask.

The reporting process is public. The specialized agencies of the UN are entitled to representation, and the Committee may invite these agencies to submit reports for its consideration. In addition, the Committee receives information informally from non-governmental organizations (NGOs). While some do attend the Committee's sessions, there is no formal procedure that allows the Committee to receive information or representations from NGOs.

\section{Constructive Dialogue}

As of February 4, 1994, the Committee had considered 72 initial, 42 second and 12 third reports. It had also received two reports on an exceptional basis - one from Bosnia and Herzegovina and one from Serbia and Montenegro.

The Committee's review of national reports is not intended to be an adversarial process. Every effort is made to develop a constructive dialogue between the country and the Committee in an atmosphere that promotes a free exchange of ideas, information and suggestions. In that spirit, the Committee never formally pronounces a state to be in violation of the Convention, but instead points out shortcomings in a series of questions and answers.

In their national reports, the Committee encourages states to set out the positive steps they have taken toward eliminating discrimination against women, acknowledging frankly any problem areas or obstacles to change. The Committee is interested in the actual position of women in their societies, not measures that exist on paper to provide for legal and formal equality. The Committee's view is that women's actual position is best measured quantitatively, as well as qualitatively, and therefore encourages the submission of statistical information.

During the review process, the Committee's questions to country representatives have ranged widely. They have covered such issues as women's economic position; the impact of structural adjustment policies; maternity leave; measures taken to allow women to combine child-bearing with employment; violence against women; the dissemination of CEDAW and its provisions within the country; and the extent to which NGOs have been incorporated into the process of preparing the report. Over the last three years, the Committee has addressed the difficulty of ensuring the protection and enjoyment of women's rights at times of transition and national crisis, particularly in the context of armed conflict.

As the Committee has shifted its focus from the consideration of initial reports to the examination of second and subsequent reports, it has iricreasingly sought to understand trends in different countries in order to assess progress and identify remaining obstacles to the full realization of CEDAW's goals.

\section{General Recommendations}

Two standing working groups meet during the Committee's regular sessions: Working Group I considers ways to expedite the Committee's work; Working Group II considers ways to implement Article 21 of the Convention, which authorizes the Committee to issue suggestions and General Recommendations on implementing CEDAW's provisions, based on its examination of the reports and information received from states parties. 
The General Recommendations issued by the Committee to date have not addressed individual states; rather, they have apprised all states parties of specific steps that may be taken to fulfil their obligations under the Convention. During its first decade, the Committee issued General Recommendations that were short and general. At its tenth session, the Committee decided that beginning in 1992, it would prepare comments on particular articles of the Convention, or on themes that cut: across a number of articles. These comments would be formulated on the basis of the Committee's examination of national reports as well as input from the Secretariat, the specialized agencies and other UN organs, NGOs and interested individuals. On this basis, the Committee agreed to examine gender-based violence against women in 1992, the family in 1993 and equality and political participation in 1994.

As a result of these comments, the Committee's General Recommendations have, since 1992, been more detailed and comprehensive and have offered states clear guidance on the application of CEDAW in particular situations. Perhaps most important is General Recommendation 19, concerning gender-based violence against women - an issue that is not addressed directly in the Convention. General Recommendation 19 defines gender-based violence as a form of discrimination against women.

\section{Reservations}

The Convention permits ratification subject to reservations, provided that the reservations are not incompatible with the object and purpose of the Convention. Countries have filed many formal reservations to CEDAW-perhaps more than to any other major human rights treaty. Some of these reservations limit the obligations undertaken by that country in vague and sweeping terms, others concern areas of fundamental importance to the achievement of women's equality, such as family law. Some reservations do, indeed, appear to be inconsistent with CEDAW's object and purpose.

The Convention does not, however, provide clear criteria or procedures for determining a reservation's compatibility; moreover, in 1984 the UN Legal Advisor concluded that making this judgement is outside the scope of the Committee. Nevertheless, the Committee has consistently raised the issue of reservations both within the United Nations and in the examination of national reports. The Committee has now formally amended its reporting guidelines, requiring states that have filed substantive reservations to report specifically on those reservations in their periodic reports.

\section{Bringing the Convention to Life}

Ratification of CEDAW has affected states parties in different ways. Some, such as Brazil, have drafted new constitutions that reflect the Convention's goals. Others, such as Australia, have introduced legislation prohibiting sex discrimination or entrenching affirmative action policies. Still others have pursued the provisions of the Convention through national plans and policy directives. Sweden has established an Equal Opportunity Ombudsman.

In a number of countries, the Convention has influenced litigation. In Tanzania, for example, CEDAW's provisions were used to reverse a discriminatory customary law relating to clan land. In Botswana and Zimbabwe, judges have used CEDAW to prohibit discrimination against women in citizenship laws.

Furthermore, in some countries, both the Convention and its reporting and implementation process, have been brought to life in domestic political activity and policy formulation. For example, Sweden's third report was compiled by 29 contributors representing NGOs, political parties and the government.

It is possible, however, that CEDAW has been most fully and powerfully brought to life by those NGOs that have used it as the benchmark for women's equality, using it to campaign for women's rights at the national, regional, and local level. In so doing, these groups have truly reclaimed women's rights as human rights. 


\section{Convention on the Elimination of All Forms of Discrimination against Women}

\section{Political Participation}

Recent decades have witnessed advances in women's political participation. In many parts of the world, both South and North, women's organizations, networks and movements have grown in number and strength and have begun to influence local, national, and international politics. At the same time, a few individual women have attained high political office.

Despite these gains, gender discrimination remains a formidable barrier to women's participation in formal decision-making processes and their control of material and political resources. There is still no country in the world where women enjoy political status, access or influence equal to that of men. As we edge towards the next century, most decisions that will decisively affect the future of this planet are being made without the input of half of its inhabitants.

Globally, women are all but invisible in formal political institutions.

- Women account for only 5 to 10 per cent of the world's formal political leadership.

- Worldwide, women hold only 10 per cent of parliament seats. This figure fell by nearly three percentage points between 1989 and 1993. The greatest decrease was in the former socialist states of Eastern Europe and the former Soviet Union.

- In 160 out of the 171 national parliaments that were functioning as of June 1993, women held no more than 20 per cent of the seats. In 36 countries, women held no more than 4 per cent of the seats.

- At the ministerial level, women hold only 4 per cent of positions worldwide. In more than 80 countries, women hold no ministerial posts whatsoever. Most of the ministries headed by women deal with matters traditionally viewed as "women's concerns," such as health, welfare, culture, education and women's affairs.

- At the end of 1990, only 6 of the 159 countries represented in the United Nations had women as chief executives.

- Women are also poorly represented in most international bodies. Only one in five senior managers in the United Nations is female.

The exclusion of women from political participation is rooted in history as well as in economic and legal realities. Compared with men, women have a shorter history of participation in electoral politics, and, as a result, substantially less experience in all aspects of the political process. In most countries, women won the right to vote only within the last 30 years. Switzerland did not grant women voting rights until 1971.

Women's participation in public life is also constrained by the gender-based violence that has reached epidemic proportions in many parts of world, in both industrialized and less developed countries. In some cases, this violence reflects a backlash against women who manage to gain political sway in their communities and who encourage other women to do so.

Traditionally, theorists have tended to rely on two approaches to explain male domination of the political process. First, they have referred to women's socially determined "choices" to channel their energies into domestic concerns, especially childrearing; and second, they have cited social and cultural norms - all of the assumptions, spoken, and unspoken, that govern attitudes towards political roles and prerogatives.

(over...) 
More recent studies go beyond these theories, showing how political institutions create and perpetuate these attitudes, supporting and sustaining an exclusionary culture of politics. This culture works against even those women who do win elective office, because it sets the terms for their participation. One recent study noted, for example, that "French women elected to office... have the choice of a maledefined equality that renders them invisible or a male-defined difference that renders them secondary."

Given these options, many women around the world have chosen to work for political and social change outside of formal political institutions. However, many women and women's organizations are urging others not to give up on the "system." They point to advances in several Scandinavian countries, noting that in nations where there is a critical mass of women in politics - 30 per cent or more - women can and do make a difference, infusing a gender perspective into virtually all areas of policy-making. This is particularly likely if women in public office maintain strong ties with effective non-governmental and grass-roots women's organizations.

CEDAW provides a powerful instrument for addressing gender equity in political life. Article 7 addresses the right "to participate in the formulation of government policy and the implementation thereof and to hold public office and perform all public functions at all levels of government." The Convention takes a further step by affirming that these rights are human rights that can be claimed only when the genderbiased cultural traditions that limit them are addressed and revised. CEDAW also affirms that civil and political rights are indivisible from social and economic rights.

CEDAW not only specifies that women must have equal status with men in political and public life, it also offers a realistic working agenda for moving towards equality. Ratifying states commit themselves to a legally binding international treaty, including participation in a country-by-country reporting process. This process strengthens accountability, documenting the actions of those governments that perpetuate the male domination of political life, as well as those that expand the political participation of women. The government officials who prepare reports on practical compliance with CEDAW are often assisted by NGOs, research organizations and, women's groups. In practice, this collaboration not only bolsters accountability; it also stimulates and promotes advocacy.

Today's daunting social, economic and environmental problems cannot be addressed or resolved if we fail to tap the strength or reflect the needs of women. This necessitates putting women and women's issues on the political agenda, and securing for women the authority and political savvy to set the agenda. CEDAW takes a long stride toward that goal.

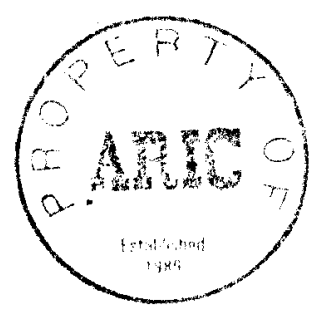

